\title{
Vertical-axis rotations and deformation along the active strike-slip EI Tigre Fault (Precordillera of San Juan, Argentina) assessed through palaeomagnetism and anisotropy of magnetic susceptibility
}

\author{
Sabrina Y. Fazzito ${ }^{1,2}$ • Augusto E. Rapalini ${ }^{1,2} \cdot$ José M. Cortés $^{1,2}$. \\ Carla M. Terrizzano ${ }^{3}$
}

Received: 6 November 2015 / Accepted: 13 April 2016 / Published online: 2 May 2016

(C) Springer-Verlag Berlin Heidelberg 2016

\begin{abstract}
Palaeomagnetic data from poorly consolidated to non-consolidated late Cenozoic sediments along the central segment of the active El Tigre Fault (Central-Western Precordillera of the San Juan Province, Argentina) demonstrate broad cumulative deformation up to $\sim 450 \mathrm{~m}$ from the fault trace and reveal clockwise and anticlockwise vertical-axis rotations of variable magnitude. This deformation has affected in different amounts Miocene to late Pleistocene samples and indicates a complex kinematic pattern. Several inherited linear structures in the shear zone that are oblique to the El Tigre Fault may have acted as block boundary faults. Displacement along these faults may have resulted in a complex pattern of rotations. The maximum magnitude of rotation is a function of the age of the sediments sampled, with largest values corresponding to middle Miocene-lower Pliocene deposits and minimum values obtained from late Pleistocene deposits. The kinematic study is complemented by low-field anisotropy of magnetic
\end{abstract}

Electronic supplementary material The online version of this article (doi:10.1007/s00531-016-1332-1) contains supplementary material, which is available to authorized users.

Sabrina Y. Fazzito

sabrinafazzito@gl.fcen.uba.ar

1 Departamento de Ciencias Geológicas, Facultad de Ciencias Exactas y Naturales, Instituto de Geociencias Básicas,

Aplicadas y Ambientales de Buenos Aires (IGEBA),

Universidad de Buenos Aires, Intendente Güiraldes 2160,

Pabellón II, Ciudad Universitaria, C1428EGA, Buenos Aires, Argentina

2 Consejo Nacional de Investigaciones Científicas y Técnicas (CONICET), Buenos Aires, Argentina

3 Institute of Geography and Oeschger Centre for Climate Change Research, University of Bern, Hallerstrasse 12, 3012 Bern, Switzerland susceptibility data to show that the local strain regime suggests a $\mathrm{N}-\mathrm{S}$ stretching direction, subparallel to the strike of the main fault.

Keywords Neotectonics · Palaeomagnetism applied to tectonics · Magnetic fabrics $\cdot$ Vertical-axis rotations $\cdot$ South America

\section{Introduction}

Palaeomagnetism, in combination with structural and geomorphic studies, is a useful tool to quantify the cumulative strike-slip deformation at different scales, from decametres (Salyards et al. 1992; Nagy and Sieh 1993) to kilometres (Ron et al. 1984; Itoh et al. 2003, 2008; Kimura et al. 2004, 2011; Mattei et al. 2012; Hernandez-Moreno et al. 2014) from the fault trace. Three decades of investigation have yielded many different kinematic and deformational models associated with strike-slip faults, from simple, fragile, domino-style systematic rotation of crustal blocks (Ron et al. 1984; Nur et al. 1986; Sylvester 1988) to distributed and ductile or fragile-ductile deformation, including heterogeneous deformational models that consider blocks of different sizes that rotate a highly variable amount and comprise opposite sense of rotations of adjacent blocks (Nelson and Jones 1987; England and Wells 1991; Sonder et al. 1994; Hernandez-Moreno et al. 2014). On the other hand, magnetic fabric analyses, defined by the anisotropy of magnetic susceptibility (AMS), have become a valuable tool for determining small amounts of internal deformation in poorly consolidated sediments in orogenic regions. However, in spite of a growing number of studies in the last two decades (Mattei et al. 1999; Sagnotti et al. 1999; Larrasoaña et al. 2011; Parés 2015), the acting mechanisms are 
not known in detail and applications in areas affected by strike-slip deformation are still scarce.

El Tigre Fault is a $120-\mathrm{km}$-long right-lateral strikeslip structure (Fig. 1; INPRES 1982; Bastías et al. 1984; Siame et al. 1997a, b; Cortés et al. 1999; Fazzito et al. 2013) located in the Central-Western Precordillera of the San Juan Province, in Argentina. The Argentine Precordillera is the seismically most active area of the whole country (INPRES 1977). In particular, the El Tigre Fault has been considered to play an important role in the seismotectonic evolution of the Andean foreland at these latitudes. In many models, it is proposed that the fault accommodates, to a large extent, the margin-parallel dextral strike-slip component of the oblique convergence vector between the Nazca and the South American Plates (Siame et al. 1997b, 2006). For this reason, the study of the kinematics of this fault is of significance to better estimate the seismic hazard of the region. In the El Tigre Fault, cumulative horizontal displacements have been measured along the fault trace by means of stream channels offset (Siame et al. 1997a, b). A maximum offset of $(260 \pm 20) \mathrm{m}$ during the late Quaternary was estimated. However, no assessment on the deformation associated with the fault mechanics in a broader scale has yet been provided. Quantification of vertical-axis rotations through palaeomagnetic measurements may prove an important tool in a thorough characterization of deformation associated with the El Tigre Fault.

We carried out the first systematic palaeomagnetic study of non-consolidated to poorly consolidated sediments around the fault in this region. A complementary study of magnetic fabrics was carried out in order to evaluate the influence of the tectonic regime in the internal deformation of sediments devoid of external signs of any tectonic disturbance and to determine whether the main regional strain directions were recorded in the sediments. The results are analysed in view of previous structural and geomorphic research, and different simplistic kinematic models for the central segment of the El Tigre Fault are proposed.

\section{General geologic setting}

The El Tigre Fault extends from $30^{\circ} 12^{\prime} \mathrm{S}$ to $31^{\circ} 14^{\prime} \mathrm{S}$ in the intermountain depression between the Sierra del Tigre, to the east, and the Sierra de la Crucecita, to the west, being limited to the north by the Jáchal River and, to the south, by the San Juan River (Fig. 1).

The study area is situated in the Western Precordillera of Argentina within the subhorizontal subduction zone of the Nazca Plate beneath South America (Fig. 1). This flatslab segment extends from $27^{\circ} \mathrm{S}$ to $33^{\circ} \mathrm{S}$ and gives rise to a series of morphotectonic units that, from west to east, are: the Frontal Cordillera, the Calingasta-Iglesia Valley, the Precordillera and the Sierras Pampeanas. The Argentine Precordillera is recognized as a fold-and-thrust belt, $400 \mathrm{~km}$ long and $80 \mathrm{~km}$ wide, uplifted during the late Cenozoic, beginning at around $16 \mathrm{Ma}$ in its northern end and becoming systematically younger up to $3.5 \mathrm{Ma}$ in its southern tip (Ramos et al. 2002 and references therein). The southern end of the Precordillera coincides with the end of the flat-slab segment, which has been interpreted as an uplift closely related to shallowing of the subducted Nazca Plate under South America in the late Cenozoic (Allmendinger et al. 1990; Kay and Abbruzzi 1996; among others). The Neogene tectonic evolution is characterized by a migration towards the east of the orogenic front and the contractional and transpressional deformation of the foreland basin (Isacks and Barazangi 1977; Jordan et al. 1983a, b; Ramos et al. 2002). At intermontane basins, folds and fault scarps that affect the piedmont areas are common (Bastías et al. 1990; Cortés et al. 1999; Costa et al. 2000). The eastern flank of the Precordillera, between $31^{\circ}$ and $34^{\circ}$ $\mathrm{S}$, concentrates most of this active deformation (Costa et al. 2006); however, evidence of neotectonic activity has also been reported at the western margin (Cortés and Cegarra 2004; Cortés et al. 2005a, b, c, 2006; Basile 2004; Vallejo 2004; Yamin 2007; Terrizzano 2010). One major example is provided by the El Tigre Fault (Bastías and Bastías 1987; Siame et al. 1997b, 2006; Cortés et al. 1999; Fazzito et al. 2013).

\section{Stratigraphy}

The Neogene sediments in the area of research are represented by the Iglesia Group, which involves the Lomas del Campanario (950 m thick) and Las Flores ( $>600 \mathrm{~m}$ thick) formations (Wetten 1975a, b; Aparicio 1984; Weidmann et al. 1985; Contreras et al. 1990; Cardó and Díaz 2005). The age of the Iglesia Group brackets between the late Miocene ( 11 Ma) and the Pliocene ( 4 Ma) as estimated by $\mathrm{Ar} / \mathrm{Ar}$ and fission track radiometric datings (Johnson et al. 1987; Re and Barredo 1993; Re 1994; Jordan et al. 1997). It is generally considered that the Las Flores Formation overlies the Lomas del Campanario Formation by a regional unconformity (Contreras et al. 1990), but Gagliardo et al. (2001) recognized an interdigitation of both units. The Lomas del Campanario Formation is made up of pyroclastic rocks, ignimbrites, andesites, tuffs, agglomerates, conglomerates and sandstones (Cardó and Díaz 2005). The Las Flores Formation is composed of finegrained laminated clastic sedimentary rocks, mostly pelites with intercalation of fine-grained sandstones and thinbedded gypsum (Bello Camilletti 2012). Alonso (2010) considered the same stratigraphic relation but considered both units as members of the same formation, called the 


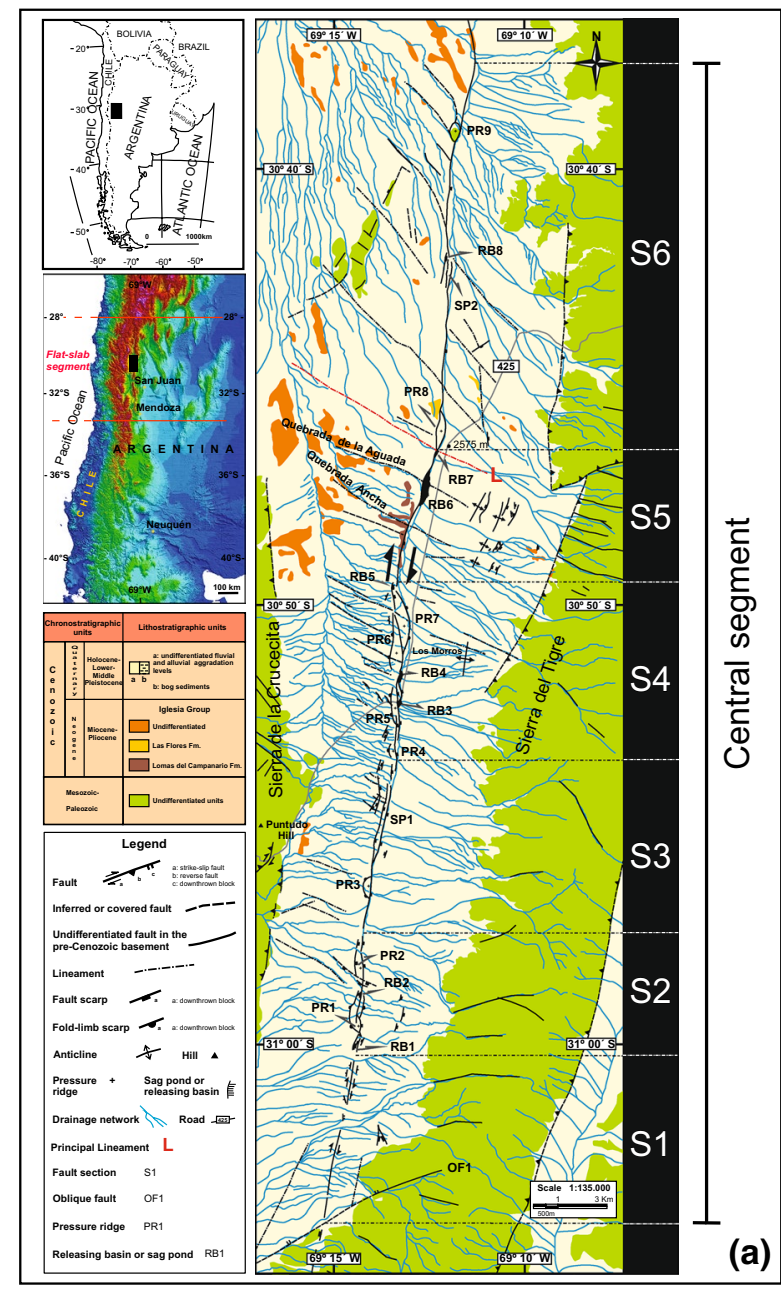

(a)

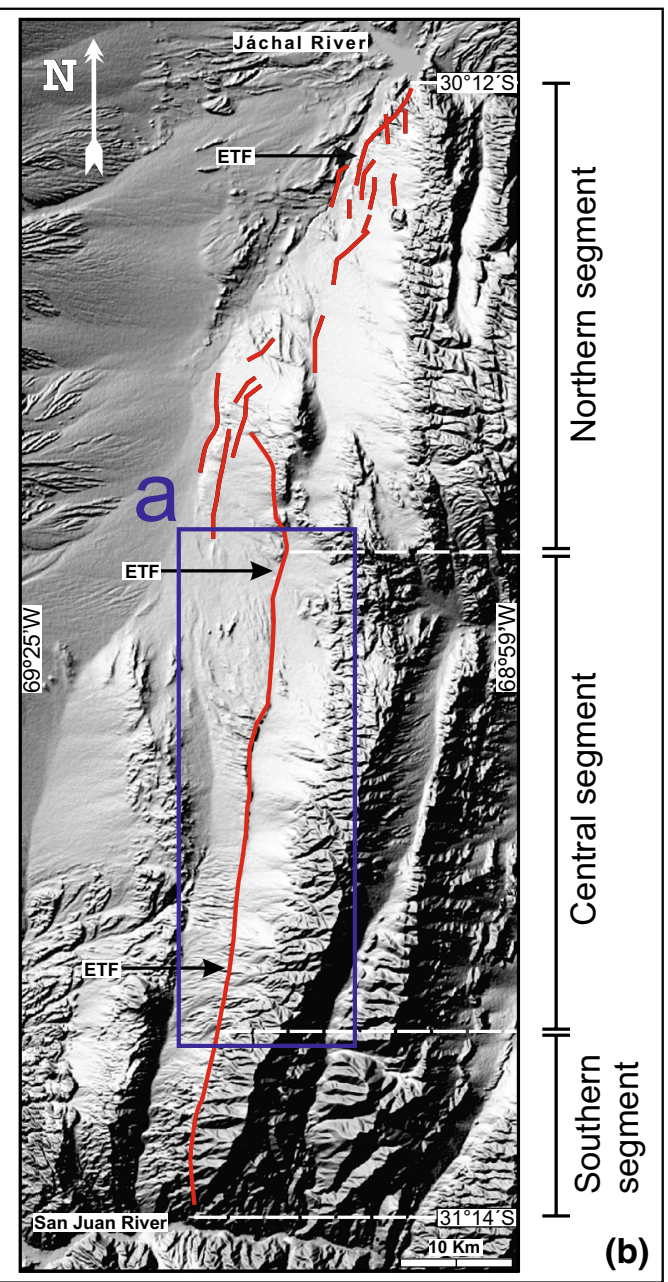

Fig. 1 a Geologic map, structure and segmentation of the central segment of the El Tigre Fault zone [modified from Fazzito (2011), Bello Camilletti (2012) and Fazzito et al. (2013)]. Main features: PR (pressure ridge), RB (releasing basin), SP (splay) and S (fault sec- tion). b The El Tigre Fault structure [after Siame et al. (1997b)] and segmentation [after Fazzito et al. (2013), modified from Siame et al. (1997b)] on Digital Elevation Model (image from SRTM, 3 arc second)

alluvial fan surfaces. Yamin (2007), however, distinguished only four regional levels and a fifth level consisting of recent sediments (Table 1). At a regional scale, and following the previous studies by Siame et al. (1997a) and Yamin (2007), we distinguished in the present work aggradation and erosion surfaces associated with the El Tigre Fault (see Table 1). In order to simplify the analysis of the palaeomagnetic data, we have subdivided the Quaternary sediments into two major units: ancient Quaternary alluvial deposits (AQAD) that comprise sediments dated between ca. 670 and $180 \mathrm{kyr}$, and young Quaternary alluvial deposits (YQAD) bracketed between ca. 100 and 20 kyr. The AQAD (middle Pleistocene) comprise most of the Quaternary sediments of the western-upthrown block of the fault. On the eastern-downthrown block, mostly at latitudes where the route 425 runs parallel to the fault (Fig. 1a), near the foothills of the Sierra del Tigre, they are preserved as remnants phologic surfaces and minimum ${ }^{10} \mathrm{Be}$ exposure dating of 
Table 1 Stratigraphic chart of the alluvial deposits associated with the El Tigre Fault according to Siame et al. (1997a, b), Yamin (2007) and this paper

\begin{tabular}{llll}
\hline Age (ka) & \multicolumn{2}{l}{ Author } & This work \\
\cline { 2 - 4 } & Siame et al. (1997a, b) & Yamin (2007) & Current and recent \\
\hline- & - & Current and recent & Young Quaternary alluvial deposits (YQAD) \\
$21 \pm 4$ & Q6 & Fourth aggradation-level deposits & \\
$42 \pm 9$ & & & \\
$99 \pm 21$ & Q5 & Third aggradation-level deposits & \\
$180 \pm 38$ & Q4 & Second aggradation-level deposits & \\
$280 \pm 58$ & Q3 & & \\
$350 \pm 72$ & Q2 & First aggradation-level deposits alluvial deposits (AQAD) \\
No data & Q1 & \\
$580 \pm 120$ & & \\
$670 \pm 140$ & &
\end{tabular}

of dissected alluvial fans. The YQAD (late Pleistocene) extend broadly over the entire downthrown block of the El Tigre Fault, surrounding the outcrops of the AQAD. In the western-upthrown block, fluvial valleys were filled by the YQAD. The YQAD reach a lower height than the AQAD, and their aggradation surfaces are less weathered. The genesis of the aggradation levels has been assigned to climatic factors due to their regional distribution (Yamin 2007) and their correlation with interglacial stages (Siame et al. $1997 \mathrm{a}, \mathrm{b})$. However, in the upthrown block of the fault, erosion levels that are not necessarily correlated with the main aggradation levels have been distinguished. They are probably associated with changes in the base level that are a result of tectonic uplifts in the fault zone (Fazzito 2011).

\section{The El Tigre Fault}

El Tigre Fault is a 120-km-long right-lateral strike-slip structure with an approximate north-south trend $\left(\sim \mathrm{N} 7^{\circ} \mathrm{E}\right)$ and an uplifted western block on its central sector (see Fazzito et al. 2013 and references therein). Quaternary activity of this fault is revealed by geomorphologic features (fault scarps, releasing basins, pressure ridges and offset streams) and disruptions of Pleistocene surfaces (INPRES 1982; Bastías and Bastías 1987; Bastías et al. 1990, 1993; Siame et al. 1996, 1997b, 2006; Cortés et al. 1999; Fazzito et al. 2013, Fig. 1a). Along its southern sector, Cenozoic deformation exposes the Palaeozoic bedrock of the Sierra del Tigre, while, in the study area, the structure affects Neogene successions of the Iglesia Group (Lomas del Campanario and Las Flores formations) and Pleistocene strata (AQAD, YQAD). Other regional structures are neighbours to the El Tigre Fault. They are, the east-vergent La
Crucecita Thrust to the west and, the thrust faults that mark the eastern margin of the Sierra del Tigre to the east (Cardó and Díaz 2005). Geologic evidence suggests that the El Tigre Fault mostly evolved before the accumulation of the late Pleistocene sediments. Since the late Pleistocene, reactivation and growth of the fault are evidenced by tectonic geomorphology. The absence of an angular unconformity between the Neogene and Quaternary sediments constraints the amount and type of deformation that affected this area in the last million years. Horizontal and vertical slip rates of 1.0 and $0.3 \mathrm{~mm} /$ year, respectively, since the late Pleistocene, were estimated from measurements of cumulative displacements and radiometric age data (Siame et al. 1997a, b, 2006).

Considering the fault geometry, Siame et al. (1997b) proposed the subdivision of the El Tigre Fault into three major parts: the northern, central and southern segments. Later, minor changes to this segmentation model were introduced by Fazzito et al. (2013) to better estimate the possible co-seismic rupture. In this case, the structure and behaviour of each segment were also evaluated. The limit between the northern (52 km long) and the central $(49 \mathrm{~km})$ segments is located at $30^{\circ} 38^{\prime} 00^{\prime \prime} \mathrm{S}$, while the limit between the central and the southern $(19 \mathrm{~km})$ segments is at $31^{\circ} 04^{\prime} 01^{\prime \prime} \mathrm{S}$ (Fig. 1b). Our study was carried out along the central segment of the El Tigre Fault.

The northern segment (Fig. 1b) comprises dispersed small fault strands spaced less than $5 \mathrm{~km}$ apart which conform a horse-tail-like fault termination (Siame et al. 1997b). Along the southern segment of El Tigre Fault (Fig. 1b), the strike-slip component of deformation is distinctly exhibited by the right-lateral offset of the drainage network entrenched in the alluvial fans in the western piedmont of the Sierra del Tigre. 
In the central segment, the El Tigre Fault is characterized by an uplifted western block bounded by a piedmont and bedrock fault scarps. Both the sediments of the Iglesia Group and the fluvial deposits of middle Pleistocene age are exposed along this fault segment due to a significant vertical component of displacement. The fault scarp has a well-defined east-facing slope $\left(18^{\circ}-24^{\circ}\right.$, Bastías et al. 1984 ) and a maximum height of $\sim 85 \mathrm{~m}$ at Los Morros zone (Siame et al. 1997b; Siame 1998; Fig. 1a). Several pressure ridges, releasing basins and splays, indicate the importance of strike-slip displacements along these segments (see Fazzito et al. 2013 and references therein) and are indicated as PR, RB and SP, respectively, in Fig. 1a. The morphometric analysis by these authors indicated two splays (SP1 and SP2), nine pressure ridges (PR1 to PR9, labelled from south to north in Fig. 1a) and nine releasing basins (RB1 to RB9 in Fig. 1a). Pressure ridges have widths from 0.30 to $0.55 \mathrm{~km}(0.40 \mathrm{~km}$ average), lengths between 0.50 and $2.2 \mathrm{~km}$ (1.44 km average) and a length/width ratio from 1.57 to 6.0 (3.59 average). Releasing basins have widths from 150 to $250 \mathrm{~m}$ ( $200 \mathrm{~m}$ average), lengths from 250 to $750 \mathrm{~m}$ (500 m average) and an average of the length/width ratio of 2.5. Indices show that the elongated form dominates both pressure ridges and releasing basins.

According to Fazzito et al. (2013), the central segment is characterized by six major sections (S1 to S6, Fig. 1a) whose lengths range from 5.0 to $7.3 \mathrm{~km}$ and whose strikes vary from $\mathrm{N}-\mathrm{S}$ to $\mathrm{N} 18^{\circ} \mathrm{E}$. Each section was determined by: (a) a pronounced change in the strike of the fault, (b) the concentration of some tectonic-related geomorphologic features and (c) the type of fault scarp. Geologic data together with results of electrical resistivity tomography led Fazzito et al. (2013) to propose a geometric model for the central segment of the El Tigre Fault in which the highangle structure alternates between a western dip and eastern dip according to the dominant inferred stress regime in each of the sections. Right and left bends of the fault plane define, respectively, transtensive (S5) and transpressive (S2, S4 and S6) sections. Sections with almost pure strike-slip kinematics (S1) and more complex behaviour (S3) were also defined.

A remarkable feature of the central segment is the presence of several lineaments and inferred faults oblique to the main fault, which seem to play a key role to accommodate the deformation along the El Tigre Fault and are probably the surface expression of basement structures (Fazzito et al. 2013; Fig. 1a). These oblique fractures are especially concentrated in sections S4, S5 and S6, and they have typically a NW-SE $\left(\mathrm{N} 134^{\circ} / 136^{\circ} \mathrm{E}\right)$ strike to the north of Quebrada Ancha and a WNW-ESE $\left(\mathrm{N} 110^{\circ} / 114^{\circ} \mathrm{E}\right)$ strike to the south of it. Among these, a particularly conspicuous lineament (Principal Lineament L, between RB7 and PR8, see Fig. 1a) has been identified as a major structural boundary that divides two areas of different kinematic characteristics of the El Tigre Fault (Fazzito et al. 2013). The vertical component of displacement of the El Tigre Fault is much more evident to the south of $\mathrm{L}$, with respect to the north of it. A greater throw of the El Tigre Fault, the disappearance of AQAD over the eastern block (western piedmont of Sierra del Tigre) and a large releasing basin (RB6) have been observed immediately to the south of this lineament. The exposed Neogene rocks change at this lineament, with outcrops of folded rocks of the Las Flores Formation to the north and virtually undisturbed poorly consolidated beds of the Lomas del Campanario Formation to the south. In addition, a change in the orientation of the drainage network from NW-SE in the north to WNW-ESE in the south and a bend in the strike of the fault trace from $\sim \mathrm{N} 5^{\circ} \mathrm{E}$ in the north to $\sim \mathrm{N} 18^{\circ} \mathrm{E}$ in the south occur at around $\mathrm{L}$ (Fazzito 2011; Fazzito et al. 2013). Furthermore, an unpublished 2D electrical resistivity tomography (Bello Camilletti 2012) orthogonal to the Principal Lineament in the area of RB7 showed a subvertical discontinuity in the distribution of rock resistivities that correlate at surface with $\mathrm{L}$ and that was interpreted as a subvertical fault with oblique displacement that uplifts the southern block.

\section{Sampling and laboratory methods}

Sampling along the central segment of the El Tigre Fault (Fig. 2) involved 36 sites typically with $8-20$ specimens at each (total of 483 samples) that were distributed around the fault trace (less than $1.2 \mathrm{~km}$ away) on middle Miocene to late Pleistocene strata (Lomas del Campanario Formation, Las Flores Formation, AQAD and YQAD). Most sites are located on the western margin of the fault where the oldest units are exposed by its vertical displacement. Oriented samples of sediments of diverse granulometry, with no evidence of macroscopic deformation, were collected by means of plastic or hydro-bronze tubes depending on the state of consolidation. A pure solution of sodium silicate was poured on the sampled sediments for the purpose of cementation prior to transportation. Well-indurated sedimentary rocks from the Las Flores Formation were obtained as hand samples. Magnetic and, whenever possible, solar compasses were used for orientation of all samples. Differences between both orientation methods were never significant. An average direction was calculated when measurements from both sun and magnetic compasses were available. The right-hand rule system was always used during sampling. Specimens have typical dimensions ranging from 25.4 to $26.0 \mathrm{~mm}$ in diameter and $22.0-25.0 \mathrm{~mm}$ in height, depending on the sampling method. Sampled sites are mostly distributed in eight main zones (named A to $\mathrm{H}$ from north to south, see Fig. 2), according to the sites 


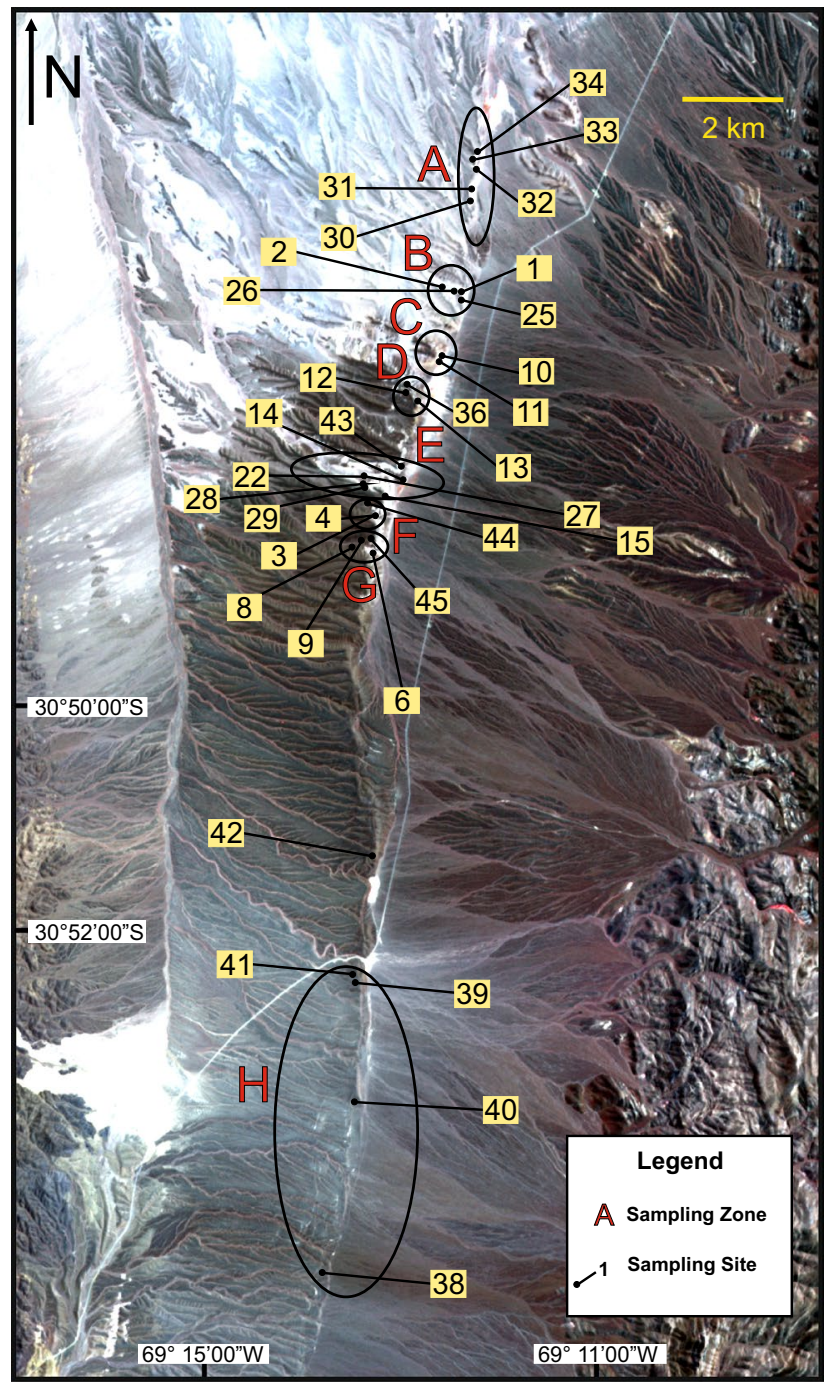

Fig. 2 Sampling sites around the central segment of the El Tigre Fault over ASTER satellite image (RGB: 321). Grouping by zones $(A-H)$ is indicated. Only sites with effective palaeomagnetic or magnetic fabric results have been included

proximity. However, each zone is separated from the others by an inferred oblique/transversal fault or lineament. The Las Flores Formation (middle Miocene-lower Pliocene) was sampled on zone A, while the Lomas del Campanario Formation (middle Miocene-lower Pliocene) was sampled on zones B, D, E and G. The AQAD were sampled on zones $\mathrm{E}, \mathrm{F}, \mathrm{G}$ and $\mathrm{H}$ and on an isolated site (T42) outside the defined zones. The YQAD were sampled on zones A, C and F. In particular, sites T3 and T4 (zone F, YQAD) were taken from two different stratigraphic levels exposed at a palaeoseismological trench orthogonal to the main fault studied by Siame (1998). Significant mesoscopic tectonic deformation is observed exclusively in the Las Flores Formation outcrops (zone A). Folded strata of deca to hectometric scale with strikes ranging from $\mathrm{N} 30^{\circ} \mathrm{E}$ to $\mathrm{N} 69^{\circ} \mathrm{E}$ are exposed at this location. Generally, three to four bedding planes were measured for each sampling site from Las Flores Formation. Mean bedding correction was calculated for each site by averaging the bedding plane poles with Fisherian statistics (Table 2). Only a single measurement was obtained at site T12 (Lomas del Campanario Formation), due to lack of suitable exposed bedding planes near the sampling area.

\section{Remanent magnetization}

Stepwise thermal demagnetization was carried out with an ASC Scientific dual-chamber furnace, while alternating field (AF) stepwise demagnetization was applied with a three-axis static degausser coupled to a $2 \mathrm{G}$ Enterprises cryogenic magnetometer (750R) with SQUID-DC sensors in the "Laboratorio de Paleomagnetismo Daniel A. Valencio" (IGEBA). When possible, two samples per site were used as pilot specimens to define the most appropriate demagnetization approach. A maximum of 11 steps up to $560{ }^{\circ} \mathrm{C}$ was sufficient to unblock the magnetization by thermal treatment $\left(50{ }^{\circ} \mathrm{C}\right.$ steps between 100 and $500{ }^{\circ} \mathrm{C}$ and two more steps of 530 and $560{ }^{\circ} \mathrm{C}$ ), and a maximum of 15 steps up to $120 \mathrm{mT}$ was used in the case of AF demagnetization (3-mT steps from 0 to $15 \mathrm{mT}, 5$-mT steps from 15 to $40 \mathrm{mT}, 10-\mathrm{mT}$ steps from 40 to $60 \mathrm{mT}$ and $20-\mathrm{mT}$ steps from 60 to $120 \mathrm{mT}$ ). All samples collected by hydro-bronze tubes (11 sites, 116 specimens) were treated by thermal demagnetization. Specimens sampled through plastic tubes (20 sites, 273 specimens) were subjected to AF demagnetization. In general, AF treatment was more efficient than thermal demagnetization.

\section{Anisotropy of low-field magnetic susceptibility (AMS)}

The anisotropy of low-field AC magnetic susceptibility $\left(H_{\text {peak }}=200 \mathrm{Am}^{-1} ; f=976 \mathrm{~Hz}\right)$ was studied with an AGICO Multi-function Kappabridge susceptibility-metre (MFK1-B) by operating in the fifteen-position protocol (Jelínek 1978; Tauxe 1998). Again, samples of sediments collected by hydro-bronze tubes had to be excluded from the measurements. Best-fitting susceptibility ellipsoid was calculated on each sample by operating the Safyr 3.2 software (AGICO, Inc.), while statistics of AMS ellipsoids on each site were computed through the Jelínek (1978) method by using the Anisoft 4.2 software developed by Chadima and Jelínek (2009). The semi-axes lengths of the ellipsoids are characterized by the principal values $k_{1}$, $k_{2}$ and $k_{3}$ (maximum, intermediate and minimum susceptibility, respectively), and the orientation is defined by the principal directions $K_{1}, K_{2}$ and $K_{3}$. Mean principal directions and respective $95 \%$ confidence ellipses on each site were determined by the statistical analysis. The magnetic 
Table 2 Site-mean characteristic remanence directions for geologic units exposed along the central segment of the El Tigre Fault

\begin{tabular}{|c|c|c|c|c|c|c|c|c|c|c|c|c|c|c|}
\hline Unit & Zone & Site & s.m. & d.m. & $n$ & $D\left(^{\circ}\right)$ & $I\left(^{\circ}\right)$ & Strike $\left({ }^{\circ}\right)$ & $\operatorname{Dip}\left({ }^{\circ}\right)$ & $D^{*}\left({ }^{\circ}\right)$ & $I^{*}\left({ }^{\circ}\right)$ & $\alpha_{95}\left(^{\circ}\right)$ & $k$ & Pol. \\
\hline \multirow[t]{5}{*}{ LF } & A & 33 & hs & $\mathrm{AF}$ & 12 & 19.8 & -58.0 & 249.0 & 26.0 & 70.9 & -69.8 & 15.5 & 8.8 & $\mathrm{~N}$ \\
\hline & A & 32 & hs & $\mathrm{AF} / \mathrm{T}$ & 6 & 0.3 & -46.9 & 225.0 & 53.0 & 76.2 & -55.4 & 7.0 & 92.5 & $\mathrm{~N}$ \\
\hline & A & 30 & hs & $\mathrm{AF} / \mathrm{T}$ & 7 & 134.8 & 81.8 & 210.0 & 30.0 & 294.5 & 67.8 & 14.6 & 18.2 & $\mathrm{R}$ \\
\hline & \multicolumn{14}{|c|}{ Sites mean (zone A) $n=3 \mathrm{Dec}=3.8^{\circ} \mathrm{Inc}=-64.4^{\circ} \alpha_{95}=30.4^{\circ} k=17.5 \mathrm{Dec} *=88.0^{\circ} \mathrm{Inc}^{*}=-65.3^{\circ} \alpha_{95}{ }^{*}=18.4^{\circ} k^{*}=45.8$} \\
\hline & \multicolumn{14}{|c|}{ Specimens mean (zone A) $n=25 \mathrm{Dec}=7.2^{\circ} \mathrm{Inc}=-63.1^{\circ} \alpha_{95}=9.9^{\circ} k=9.6 \mathrm{Dec}^{*}=83.9^{\circ} \mathrm{Inc}^{*}=-66.6^{\circ} \alpha_{95^{*}}{ }^{*}=8.6^{\circ} k^{*}=12.3$} \\
\hline \multirow[t]{21}{*}{ LC } & B & 2 & $\mathrm{~h}$ & $\mathrm{~T}$ & 10 & 24.3 & -36.3 & - & - & 24.3 & -36.3 & 7.4 & 44.0 & $\mathrm{~N}$ \\
\hline & $\mathrm{B}$ & 1 & $\mathrm{~h}$ & $\mathrm{~T}$ & 7 & 32.7 & -58.9 & - & - & 32.7 & -58.9 & 19.1 & 11.0 & $\mathrm{~N}$ \\
\hline & B & 26 & $\mathrm{~h}$ & $\mathrm{~T}$ & 7 & 197.0 & 56.7 & - & - & 197.0 & 56.7 & 10.2 & 36.0 & $\mathrm{R}$ \\
\hline & B & 25 & hs & $\mathrm{AF} / \mathrm{T}$ & 7 & 183.0 & 53.1 & - & - & 183.0 & 53.1 & 17.5 & 12.9 & $\mathrm{R}$ \\
\hline & \multicolumn{14}{|c|}{ Sites mean (zone B) $n=4 \mathrm{Dec}=19.3^{\circ} \mathrm{Inc}=-51.8^{\circ} \alpha_{95}=14.4^{\circ} \mathrm{k}=41.5$} \\
\hline & \multicolumn{14}{|c|}{ Specimens mean (zone B) $n=31 \mathrm{Dec}=19.9^{\circ} \mathrm{Inc}=-50.1^{\circ} \alpha_{95}=6.9^{\circ} k=15.2$} \\
\hline & $\mathrm{D}$ & 36 & $\mathrm{p}$ & $\mathrm{AF}$ & 11 & 25.4 & -31.8 & - & - & 25.4 & -31.8 & 15.0 & 10.3 & $\mathrm{~N}$ \\
\hline & $\mathrm{D}$ & 12 & $\mathrm{p}$ & $\mathrm{AF}$ & 6 & 210.4 & 9.8 & 135.0 & 10.0 & 210.6 & 0.1 & 17.4 & 15.8 & $\mathrm{R}$ \\
\hline & $\mathrm{D}$ & 13 & $\mathrm{p}$ & $\mathrm{AF}$ & 6 & 336.0 & -47.5 & - & - & 336.0 & -47.5 & 18.7 & 13.8 & $\mathrm{~N}$ \\
\hline & \multicolumn{14}{|c|}{ Sites mean (zone D) $n=3 \mathrm{Dec}=14.8^{\circ} \mathrm{Inc}=-31.8^{\circ} \alpha_{95}=50.0^{\circ} k=7.1 \mathrm{Dec}^{*}=14.9^{\circ} \mathrm{Inc}^{*}=-28.6^{\circ} \alpha_{95^{*}}=57.6^{\circ} \mathrm{k}^{*}=5.7$} \\
\hline & \multicolumn{14}{|c|}{ Specimens mean (zone D) $n=23 \mathrm{Dec}=17.1^{\circ} \mathrm{Inc}=-31.8^{\circ} \alpha_{95}=12.6^{\circ} k=6.7 \mathrm{Dec}^{*}=17.3^{\circ} \mathrm{Inc} *=-29.3^{\circ} \alpha_{95^{*}}=13.6^{\circ} k^{*}=6.0$} \\
\hline & E & 14 & $\mathrm{~h}$ & $\mathrm{~T}$ & 6 & 68.2 & -42.4 & - & - & 68.2 & -42.4 & 20.3 & 11.8 & $\mathrm{~N}$ \\
\hline & E & 15 & $\mathrm{~h}$ & $\mathrm{~T}$ & 3 & 227.8 & 5.5 & - & - & 227.8 & 5.5 & 20.8 & 36.2 & $\mathrm{R}$ \\
\hline & \multicolumn{14}{|c|}{ Sites mean (zone E, sites T14 and T15) $n=2 \mathrm{Dec}=56.5^{\circ} \mathrm{Inc}=-24.3^{\circ} \alpha_{95}=-k=-$} \\
\hline & \multicolumn{14}{|c|}{ Specimens mean (zone E, sites T14 and T15) $n=9 \mathrm{Dec}=59.8^{\circ} \mathrm{Inc}=-30.2^{\circ} \alpha_{95}=19.0^{\circ} \mathrm{k}=8.3$} \\
\hline & $\mathrm{E}$ & 22 & $\mathrm{p}$ & $\mathrm{AF}$ & 1 & 147.4 & 27.6 & - & - & 147.4 & 27.6 & - & - & $\mathrm{R}$ \\
\hline & $\mathrm{E}$ & 27 & $\mathrm{p}$ & $\mathrm{AF}$ & 14 & 112.1 & 45.3 & - & - & 112.1 & 45.3 & 7.9 & 26.2 & $\mathrm{R}$ \\
\hline & \multicolumn{14}{|c|}{ Sites mean (zone E, sites T22 and T27) $n=2 \mathrm{Dec}=311.8^{\circ} \mathrm{Inc}=-37.8^{\circ} \alpha_{95}=-k=-$} \\
\hline & \multicolumn{14}{|c|}{ Specimens mean (zone E, sites T22 and T27) $n=15 \mathrm{Dec}=295.0^{\circ} \mathrm{Inc}=-44.5^{\circ} \alpha_{95}=8.4^{\circ} \mathrm{k}=21.6$} \\
\hline & G & 8 & $\mathrm{~h}$ & $\mathrm{~T}$ & 9 & 286.8 & -45.1 & - & - & 286.8 & -45.1 & 8.9 & 34.0 & $\mathrm{~N}$ \\
\hline & G & 6 & $\mathrm{~h}$ & $\mathrm{~T}$ & 8 & 114.1 & 0.1 & - & - & 114.1 & 0.1 & 6.3 & 78.5 & $\mathrm{R}$ \\
\hline \multirow[t]{12}{*}{ AQAD } & $\mathrm{E}$ & 43 & $\mathrm{p}$ & $\mathrm{AF}$ & 7 & 354.2 & -35.3 & - & - & 354.2 & -35.3 & 9.0 & 45.7 & $\mathrm{~N}$ \\
\hline & F-G & 44 & $\mathrm{p}$ & $\mathrm{AF}$ & 9 & 333.7 & -51.1 & - & - & 333.7 & -51.1 & 15.6 & 11.8 & $\mathrm{~N}$ \\
\hline & F-G & 45 & $\mathrm{p}$ & $\mathrm{AF}$ & 8 & 349.0 & -46.7 & - & - & 349.0 & -46.7 & 6.5 & 74.0 & $\mathrm{~N}$ \\
\hline & \multicolumn{14}{|c|}{ Sites mean (zone $F-G) n=2 \mathrm{Dec}=341.7^{\circ} \mathrm{Inc}=-49.2^{\circ} \alpha_{95}=-k=-$} \\
\hline & \multicolumn{14}{|c|}{ Specimens mean $($ zone $F-G) n=17 \mathrm{Dec}=341.5^{\circ} \mathrm{Inc}=-49.2^{\circ} \alpha_{95}=8.4^{\circ} k=18.9$} \\
\hline & - & 42 & $\mathrm{p}$ & $\mathrm{AF}$ & 6 & 19.1 & -40.8 & - & - & 19.1 & -40.8 & 12.6 & 29.4 & $\mathrm{~N}$ \\
\hline & $\mathrm{H}$ & $41^{\mathrm{a}}$ & $\mathrm{p}$ & $\mathrm{AF}$ & 6 & 317.0 & -36.6 & - & - & 317.0 & -36.6 & 14.3 & 22.8 & $\mathrm{~N}$ \\
\hline & $\mathrm{H}$ & 39 & $\mathrm{p}$ & $\mathrm{AF}$ & 10 & 16.4 & -41.9 & - & - & 16.4 & -41.9 & 7.1 & 47.7 & $\mathrm{~N}$ \\
\hline & $\mathrm{H}$ & 40 & $\mathrm{p}$ & $\mathrm{AF}$ & 13 & 0.6 & -45.9 & - & - & 0.6 & -45.9 & 8.4 & 25.5 & $\mathrm{~N}$ \\
\hline & $\mathrm{H}$ & 38 & $\mathrm{p}$ & $\mathrm{AF}$ & 11 & 12.5 & -21.0 & - & - & 12.5 & -21.0 & 8.3 & 31.6 & $\mathrm{~N}$ \\
\hline & \multicolumn{14}{|c|}{ Sites mean (zone $H$ ) $n=3 \mathrm{Dec}=10.2^{\circ} \mathrm{Inc}=-36.5^{\circ} \alpha_{95}=22.8^{\circ} \mathrm{k}=20.2$} \\
\hline & \multicolumn{14}{|c|}{ Specimens mean (zone H) $n=34 \mathrm{Dec}=9.6^{\circ} \mathrm{Inc}=-36.9^{\circ} \alpha_{95}=5.8^{\circ} k=19.2$} \\
\hline \multirow[t]{8}{*}{ YQAD } & $\mathrm{C}$ & 10 & $\mathrm{p}$ & $\mathrm{AF}$ & 7 & 12.8 & -34.1 & - & - & 12.8 & -34.1 & 19.6 & 10.4 & $\mathrm{~N}$ \\
\hline & $\mathrm{C}$ & 11 & $\mathrm{p}$ & $\mathrm{AF}$ & 6 & 7.7 & -34.7 & - & - & 7.7 & -34.7 & 19.7 & 12.6 & $\mathrm{~N}$ \\
\hline & Sites $n$ & $n$ (zone & $n=2$ & $=10.3$ & $c=-$ & $4^{\circ} \alpha_{95}=$ & $k=-$ & & & & & & & \\
\hline & Specir & mean & ne C) $r$ & $13 \mathrm{Dec}$ & $0.4^{\circ}$ & $=-34$ & $95=12.4$ & $=12.2$ & & & & & & \\
\hline & $\mathrm{F}$ & 3 & $\mathrm{p}$ & $\mathrm{AF}$ & 13 & 13.8 & -48.2 & - & - & 13.8 & -48.2 & 5.7 & 54.6 & $\mathrm{~N}$ \\
\hline & $\mathrm{F}$ & 4 & $\mathrm{p}$ & $\mathrm{AF}$ & 10 & 352.1 & -48.8 & - & - & 352.1 & -48.8 & 6.1 & 63.2 & $\mathrm{~N}$ \\
\hline & Sites $n$ & $n$ (zone & $n=2$ & $=2.9^{\circ}$ & $=-$ & $5^{\circ} \alpha_{95}=$ & $=-$ & & & & & & & \\
\hline & Specin & s mean & ne F) $n$ & $23 \mathrm{Dec}=$ & $4^{\circ} \mathrm{Ir}$ & $=-48.9^{\circ}$ & $5=4.8^{\circ} k$ & 41.0 & & & & & & \\
\hline
\end{tabular}

Sites are presented by geologic unit and from north to south. LF: Las Flores Formation; LC: Lomas del Campanario Formation; AQAD: ancient Quaternary alluvial deposits; YQAD: young Quaternary alluvial deposits; s.m.: sampling method (hs: hand sample; h: sampling by hydro-bronze cylinders; p: sampling by cylindrical plastic containers); d.m.: demagnetization method (AF: alternating field; T: thermal); $n$ : number of specimens used to compute the site-mean direction; $D, I$ : site-mean declination and inclination, respectively; Strike, Dip: strike and dip of bedding, respectively; $\alpha_{95}$ : half-angle of the cone of $95 \%$ confidence about the mean; $k$ : Fisher's precision parameter; Pol: remanence polarity (N: normal, R: reverse). Sites mean and specimens mean are calculated (Dec: declination; Inc: inclination; $\alpha_{95}, k$ : statistical parameters of Fisher (1953))

* Bedding corrected data

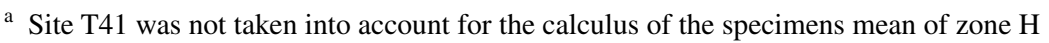


anisotropy was quantified by standard parameters such as $P_{j}$ (corrected anisotropy degree), which indicates the eccentricity of the anisotropy ellipse, and $T$, which defines the shape of the anisotropy ellipsoids, ranging from -1 (a prolate ellipsoid of revolution, i.e. $k_{2}=k_{3}$ ) to +1 (an oblate ellipsoid of revolution, i.e. $k_{1}=k_{2}$ ). The arithmetical mean of the susceptibility $(k)$ was also estimated for each site.

\section{Thermomagnetic curves}

Temperature dependence of magnetic susceptibility for samples from the four geologic units was studied with an AGICO Kappabridge (MFK1-FA) susceptibility-metre coupled to high-temperature (CS4) and low-temperature (CSL) controllers. Temperature range varied from $\sim-187{ }^{\circ} \mathrm{C}$ to room temperature in air (low-temperature curve) and from room temperature to $685{ }^{\circ} \mathrm{C}$ (high-temperature curve) in an argon-controlled atmosphere. The peak external field was set at $200 \mathrm{Am}^{-1}$ and its frequency at $976 \mathrm{~Hz}$. Heating rate was about $13.5{ }^{\circ} \mathrm{C} / \mathrm{min}$ (low-temperature curve) and $3 .{ }^{\circ} \mathrm{C} / \mathrm{min}$ (high-temperature curve). Low temperatures were reached by use of liquid nitrogen $(\sim 77 \mathrm{~K})$.

\section{Field and frequency dependence of magnetic susceptibility}

Field and frequency variation of magnetic susceptibility were studied to help on the identification of ferromagnetic minerals and characterization of their grain size, respectively. Curves of variation of bulk magnetic susceptibility as a function of a peak AC field from 2 to $700 \mathrm{Am}^{-1}$ at a fix frequency of $976 \mathrm{~Hz}$ were obtained on different samples from the four geologic units with an AGICO Kappabridge (MFK1-FA). Also, measurements of bulk susceptibility at $200 \mathrm{Am}^{-1}$ at two different frequencies $f_{1}(976 \mathrm{~Hz})$ and $f_{3}(15,616 \mathrm{~Hz})$ were imparted on several specimens from every sampling zone. The frequency dependence of magnetic susceptibility was evaluated through the parameter $k_{f \mathrm{~d}}(\%)=100 \times\left(k_{f 1}-k_{f 3}\right) / k_{f 1}$.

\section{Isothermal remanent magnetization and backfield}

Ferromagnetic mineralogy was studied using curves of the acquisition of isothermal remanent magnetization (IRM) of representative specimens from every zone by using an ASC Scientific IM-10-30 pulse magnetizer from 3 to $2300 \mathrm{mT}$ and an AGICO spinner magnetometer (JR-6). Afterwards, backfield demagnetization of IRM measurements was imparted to these samples to evaluate the remanent coercive force $\left(B_{\mathrm{cr}}\right)$ of the ferromagnetic minerals. Cumulative log-Gaussian functions (CLG, Robertson and France 1994) were used to analyse the magnetic coercivity components of some of these curves by the three fitting procedures
Fig. 3 Representative vector component diagrams (Zijderveld plots) of samples treated by progressive alternating field (AF) or thermal demagnetization. Open (solid) symbols represent the projection on the vertical (horizontal) plane. Important demagnetization steps have been indicated. NRM: natural remanent magnetization; LF: Las Flores Formation (light blue); LC: Lomas del Campanario Formation (green); AQAD: ancient Quaternary alluvial deposits (orange); YQAD: young Quaternary alluvial deposits (purple). Sites are mostly arranged by latitude

(LAP, GAP and SAP) included in the software developed by Kruiver et al. (2001). Values of SIRM (saturation of isothermal remanent magnetization), $B_{1 / 2}$ (applied field at which half of the SIRM is reached) and dispersion parameter DP (half-width of the distribution) were estimated.

\section{Results}

\section{Palaeomagnetism}

Interpretable palaeomagnetic results were obtained from samples from 28 sites (226 samples, Table 2, see their location in Fig. 2) located within a distance of about $420 \mathrm{~m}$ from the fault trace. Eight sites (one site from Las Flores Formation, six sites from Lomas del Campanario Formation and one site from YQAD) showed lack of intra-site directional coherence. Representative Zijderveld diagrams (Zijderveld 1967) are presented in Fig. 3. In most cases, stepwise demagnetization permitted the isolation of a characteristic component, with both $\mathrm{AF}$ and thermal treatment. Some thermal demagnetization curves from Las Flores Formation (sites T30, T31, T32 and T33) reveal partial intensity decay at about $150{ }^{\circ} \mathrm{C}$, which suggests the presence of goethite. Unblocking temperatures between 350 and $400{ }^{\circ} \mathrm{C}$ and low-to-medium destructive fields $(\leq 50 \mathrm{mT})$ in sites T30, T31, T32 and T33 are consistent with the presence of titanomagnetite or maghemite as the main carrier. After AF demagnetization at $120 \mathrm{mT}$, some samples from Las Flores Formation (e.g. T33-1A1, Fig. 3) preserve $10-20 \%$ of the initial remanence confirming a subordinate contribution of a high coercivity magnetic mineral (goethite, haematite). In the Lomas del Campanario Formation (sites T1, T2, T6, T8, T14, T15, T25 and T26), highest unblocking temperatures in the range of $500-550{ }^{\circ} \mathrm{C}$ reveal that Ti-poor titanomagnetite carries the characteristic magnetization. Several samples at some of these sites (T1, T2, T6, T15, T25 and T26) show pronounced remanence decay at lower temperatures, generally ranging from 250 up to $350{ }^{\circ} \mathrm{C}$, which suggests a low-stability component either carried by Ti-rich titanomagnetite, maghemite or by large PSD-MD Ti-poor titanomagnetite grains. The characteristic component of samples from the AQAD and YQAD shows an univectorial decay towards the origin of the Zijderveld diagrams 

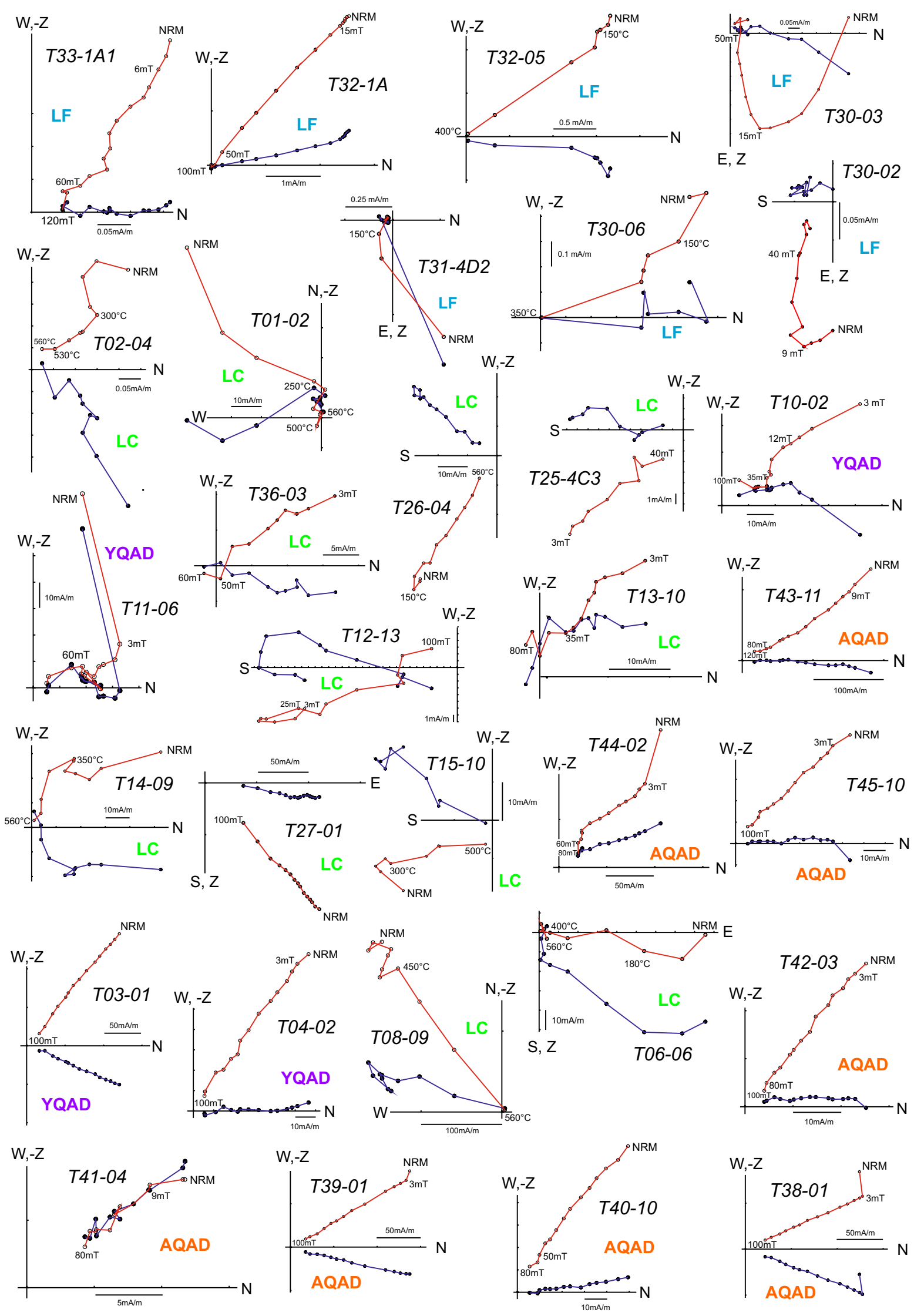
(Fig. 3). Most of it is erased at fields higher than $12 \mathrm{mT}$, but in general it is not completely removed by the AF demagnetization method $(<20 \%$ of the original intensity survived fields of 100-120 mT). This suggests that titanomagnetite is probably the main carrier of this magnetization and that a higher coercivity component as goethite and/or haematite carries the same remanence direction.

Components of magnetization were isolated by principal component analysis (PCA; Kirschvink 1980) on the basis of the Zijderveld plots with support of the SuperIAPD2000 software (Torsvik et al. 2000). Only components with less than $16^{\circ}$ of maximum angular deviation (MAD) were considered interpretable. Most sites display two components of magnetization. The low-unblocking-temperature or low-coercivity components (typically in the range $0-250{ }^{\circ} \mathrm{C}$ or $0-15 \mathrm{mT}$ ) are attributed to a secondary magnetization of recent age, probably as a result of viscous overprints, since their directions resemble that of the present-day field at the study locality or are randomly distributed. The high-stability characteristic magnetization component was isolated usually between 250 and $500{ }^{\circ} \mathrm{C}$ or 15 and $60 \mathrm{mT}$. Only in a few samples from sites T8 (Lomas del Campanario Formation) and T30 (Las Flores Formation) a third component was observed, although not erased by AF (e.g. T30-02, Fig. 3), which also has been interpreted as a secondary magnetization carried by an antiferromagnetic fraction. Spherical statistics (Fisher 1953) were first used to calculate the mean direction of the magnetic components for each site. Some sites (T5, T9, T28, T29, T31, T34, T35 and T37) did not show directional consistency. Sampling procedures of unconsolidated sediments may bias the remanence and/or AMS directions, but in our case no correlation was found between the sample orientation and any of these magnetic directions. Mean magnetic directions and statistical parameters of the characteristic component are given in Table 2 . This remanence is of both reverse (eight sites, see Table 2) and normal polarity (twenty sites, Table 2). To deal with more representative data, whenever possible remanence directions for specimens from sites at the same zone were averaged for each geologic unit (Table 2). Equal-area projections of site-mean and zone-mean characteristic magnetic directions are plotted in Fig. 4. At zone A, where the Las Flores Formation shows significant folding, application of the Watson and Enkin (1993) fold test to the site-mean as well as the specimen-mean directions (Fig. 5a, b) indicates a pre-folding remanence. The precision parameter $k$ reaches the maximum value (i.e. clustering of directions is maximum) at $95 \%$ of bedding correction in the first case and at $92 \%$ in the second case. This strongly suggests a primary remanence for the Las Flores Formation. The remaining sites were located in flat-lying sediments, so that no fold or tilt test was possible to determine the timing of remanence acquisition. However, the recording of both geomagnetic polarities in zones A, B, D and E (Las Flores and Lomas del Campanario formations) suggests that the remanence is ancient, probably primary, and the palaeosecular variation has been mostly averaged by these deposits. Large values of rotations found in several sites (see "Vertical-axis rotations" section) also argue against any recent remagnetization of these sediments. The normal polarity found in all samples from AQAD and YQAD is consistent with the age estimates obtained by ${ }^{10} \mathrm{Be}$ cosmogenic dating (Siame et al. 1997a), indicating that these sediments were deposited during the Brunhes chron.

\section{Magnetic mineralogy}

All IRM acquisition and backfield curves from Lomas del Campanario Formation, AQAD and YQAD (Fig. 6b-d) show analogous behaviour. Saturation occurs at magnetic fields below 1T and 90-92\% of it is reached at $300 \mathrm{mT}$. Backfield curves indicate, for these three units, remanent coercive force values $\left(B_{\mathrm{cr}}\right)$ in the range of $14-52 \mathrm{mT}$ and a weighted mean of $36 \mathrm{mT}$ (Table 3; Fig. 6). This range is compatible with titanomagnetite (see typical values of $B_{\mathrm{cr}}$ in Peters and Dekkers 2003), suggesting that maghemite is not a likely carrier in the Lomas del Campanario Formation. On the other hand, pyrrhotite is not a likely carrier considering the results of field dependence of susceptibility (Fig. 8b) together with geologic evidence of oxidizing environments both during deposition and diagenesis of the sediments. In the Las Flores Formation, however, three types of IRM acquisition curves are observed (Fig. 6a). Curves from samples T30-3 and T32-2A1 are similar to those from other units. In fact, the remanent coercive forces of both specimens ( 36 and $37 \mathrm{mT}$, respectively; Table 3) are almost identical to the weighted mean of those three units. The other acquisition curves clearly show the presence of two magnetic phases, which are interpreted as titanomagnetite and an antiferromagnetic mineral. These samples show either a significant contribution of the ferrimagnetic phase (T31-1C1 and T32-2B) with values of $B_{\text {cr }}$ of 52 and $55 \mathrm{mT}$, or a much lower presence of this phase (T33-2B and T33-3B) and dominance of the antiferromagnetic component, as backfield curves indicate remanent coercive forces $\left(B_{\mathrm{cr}}\right)$ of 200 and $508 \mathrm{mT}$, respectively. These values are compatible with high goethite or haematite content (Table 3). Maghemite is not a likely carrier of the lower coercivity component in Las Flores Formation, considering that $B_{\mathrm{cr}}$ of this mineral is higher than $36 \mathrm{mT}$ (Table 3).

Cumulative log-Gaussian functions (CLG, Robertson and France 1994) were used to analyse IRM acquisition curves of samples from Las Flores Formation. Fitting parameters (Table 4) obtained by using the specific software of Kruiver et al. (2001) corroborate the previous interpretations. A bimodal distribution of coercivity spectra is observed for all these samples (except for T32-2A1, which is unimodal). Taking into account the values of $B_{1 / 2}(\geq 50.1 \mathrm{mT})$, the lower coercivity phase is associated with titanomagnetite, while the higher coercivity phase of samples T31-1C1, 

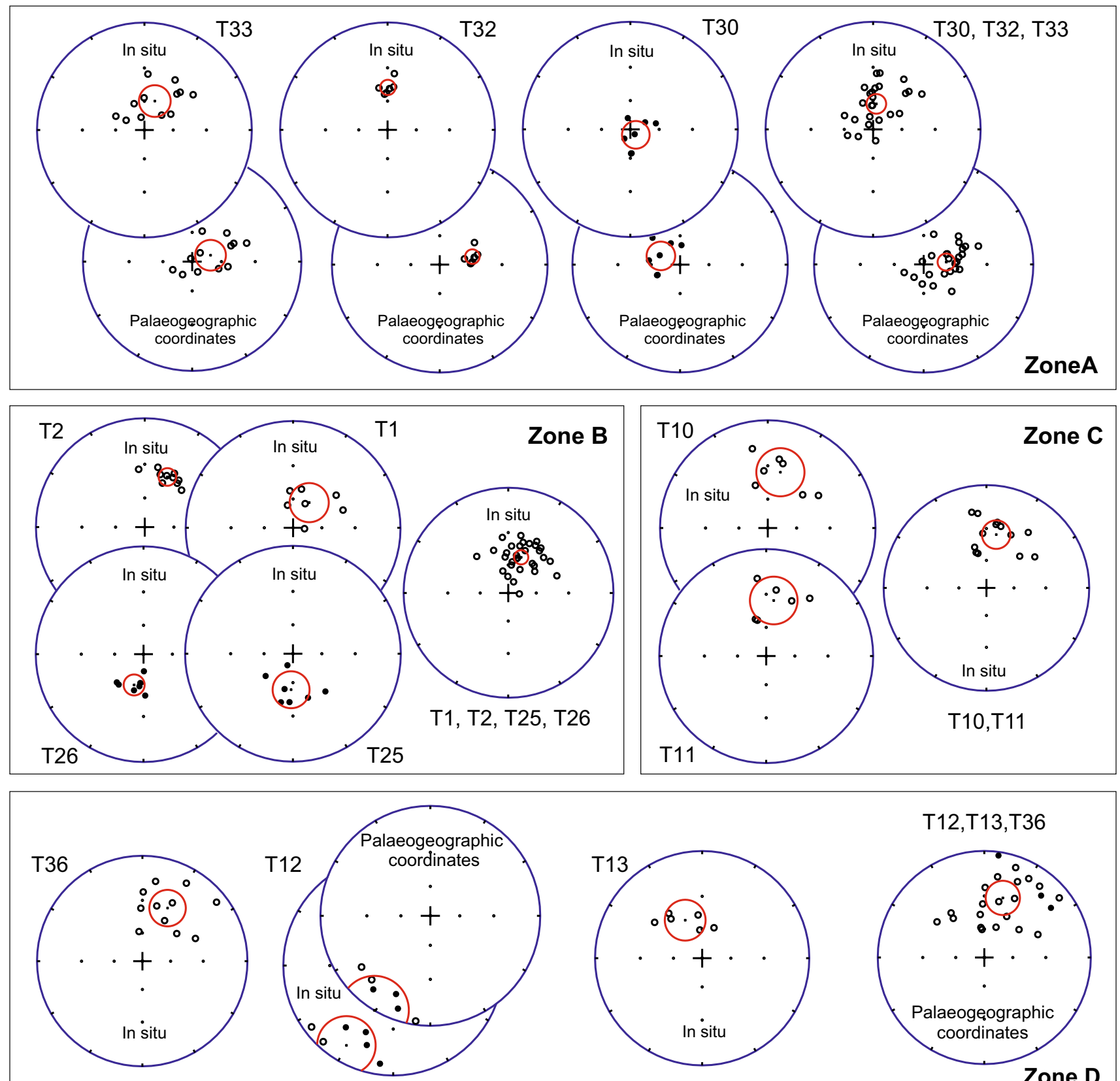

$\mathrm{T} 12, \mathrm{~T} 13, \mathrm{~T} 36$
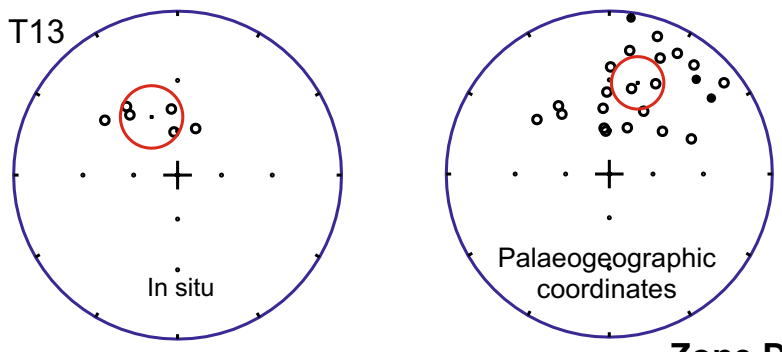

Fig. 4 Equal-area projection (lower hemisphere) of site-mean (T42) or zone-mean characteristic remanence directions. At every zone, statistics is applied all over the samples. Open (close) symbols correspond to

normal (reverse) polarity. Confidence ellipses of $95 \%$ are represented. Directions of sites T12, T15, T25, T26 and T30 are inverted for the zone-mean. Sites are mostly presented from north to south

T32-2B and T33-2B corresponds to goethite and T30-03 and T33-3B to goethite/haematite (see evidence of haematite in thermomagnetic curve from site T30; Fig. 7).

Thermomagnetic curves (susceptibility vs. temperature) of Lomas del Campanario Formation, AQAD and YQAD show properties that are independent of rock type (Fig. 7). The curves show a high Curie temperature typical of a population of Ti-poor titanomagnetite $\left(\sim 580^{\circ} \mathrm{C}\right)$ and a certain amount of haematite $\left(T_{\mathrm{N}}=680{ }^{\circ} \mathrm{C}\right)$, also suggested

by incomplete demagnetization of the NRM at $100 \mathrm{mT}$ (Fig. 3). However, the IRM acquisition curves (Fig. 6) from these formations suggest that contribution of haematite is clearly subordinate. Low-temperature peaks between -151 and $-172{ }^{\circ} \mathrm{C}$ for all the specimens suggest the Verwey transition which is indicative of PSD-MD magnetite (Dearing 1994). SD magnetite in samples of Lomas del Campanario Formation is, however, suggested by small Hopkinson peaks (Dunlop and Özdemir 1997). A distribution 

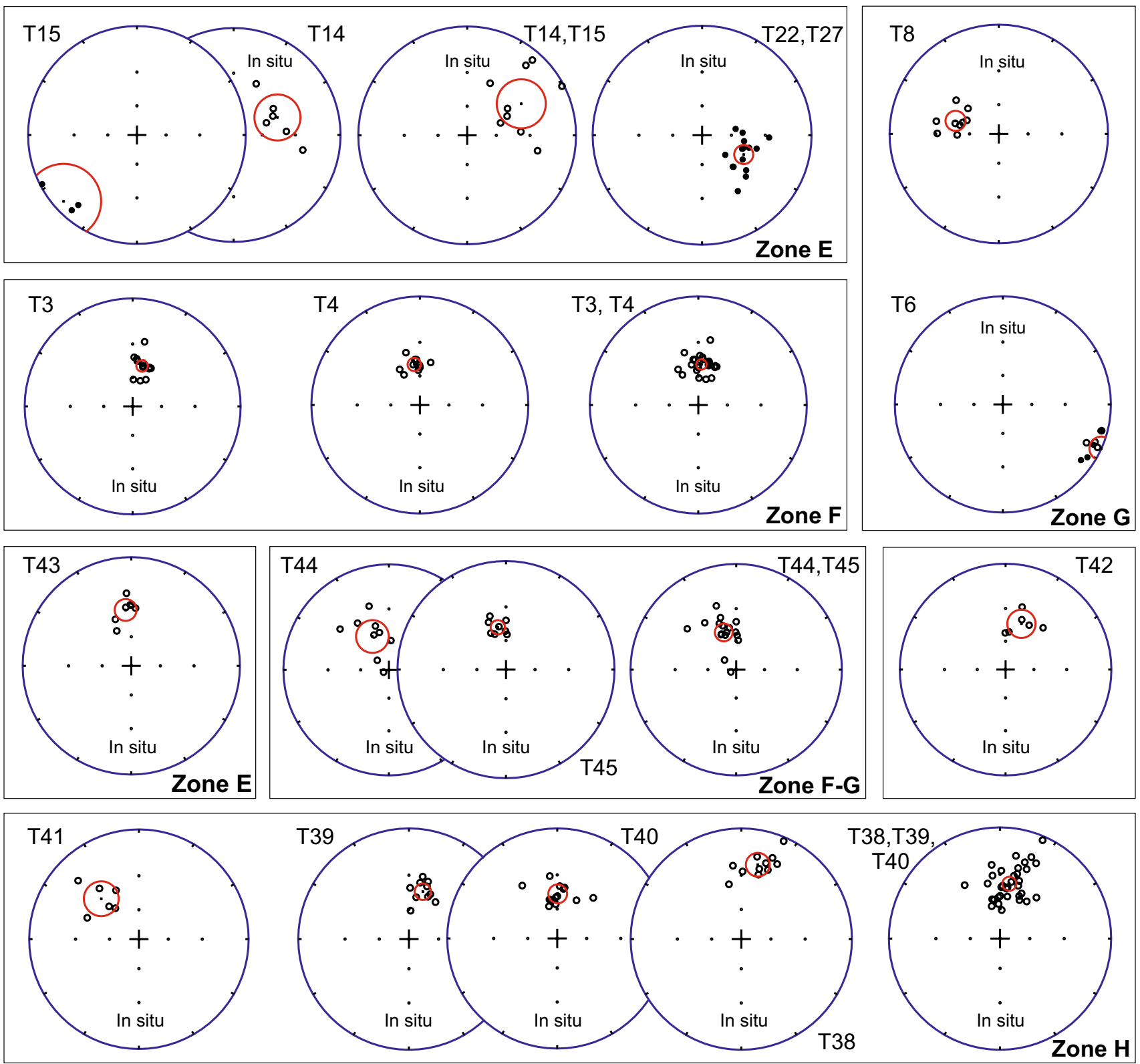

Fig. 4 continued

of grain sizes from SD to MD magnetite is therefore likely. As in Lomas del Campanario Formation, thermomagnetic curves of Las Flores Formation (see an example in Fig. 7a) show a high Curie temperature $\left(\sim 580{ }^{\circ} \mathrm{C}\right)$ and Hopkinson peaks which indicate the presence of SD Ti-poor titanomagnetites. Low haematite content is also present. No Verwey transition is observed in this case. An important fraction of magnetic minerals (mainly magnetite) is generated during heating, as the process is not reversible, showing an increase in susceptibility in the cooling curve.

Field variation of susceptibility is very low for all lithologies, with $k_{\text {hd }}<4 \%$ (see Fig. 8). All selected samples from Lomas del Campanario Formation, AQAD and YQAD (Fig. 8a) present monotonically increasing curves (mostly concave-down) for fields higher than $10 \mathrm{Am}^{-1}$. From these results, the prevailing magnetic mineral in these sediments is likely titanomagnetite with variable titanium content (Worm et al. 1993; Hrouda et al. 2006). Curves of samples from Las Flores Formation (Fig. 8b) show very small to non-significant increase in most part of the field range (for fields higher than $100 \mathrm{Am}^{-1}$ ), which may suggest that susceptibility is governed by antiferromagnetic, paramagnetic or Ti-poor titanomagnetite minerals. 


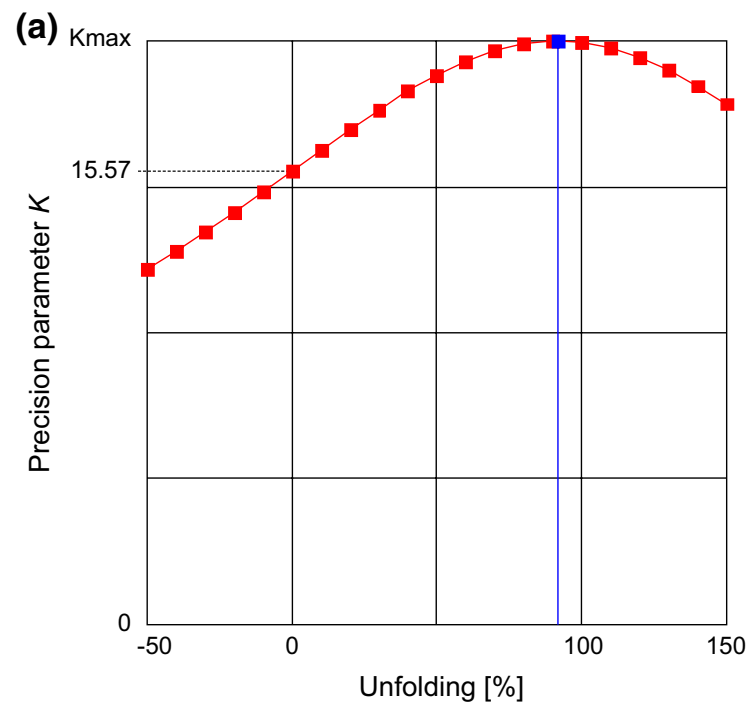

Fig. 5 Watson and Enkin (1993) fold test on the characteristic component from samples of zone A. a Statistics applied over the mean directions of magnetization of the three sites. b Statistics applied all

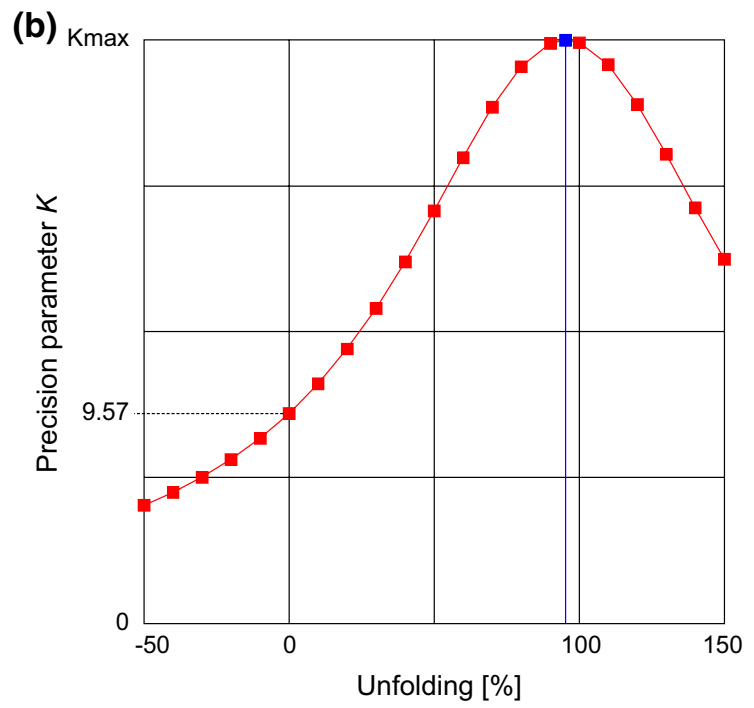

over the directions of magnetization of the entire set of samples from Las Flores Formation

\section{(a)}

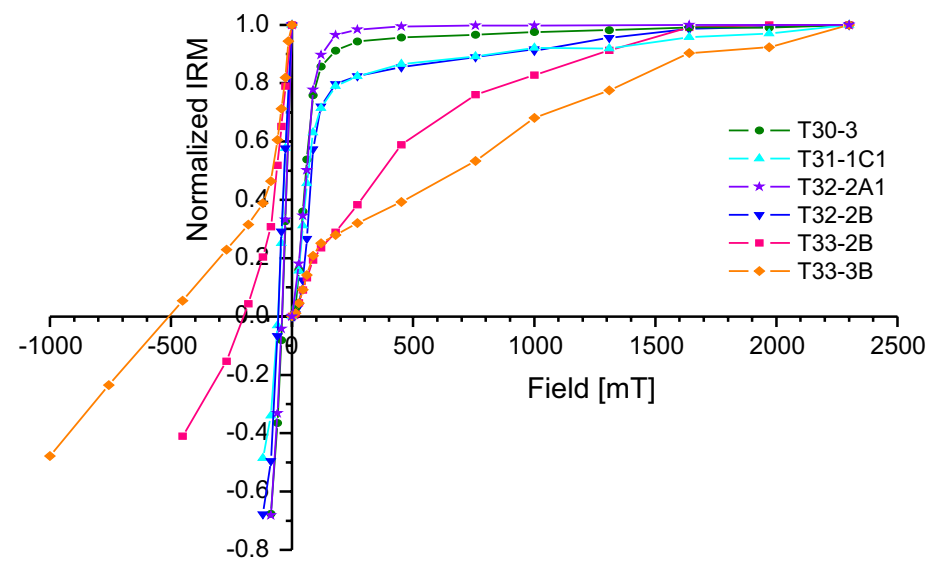

(c)

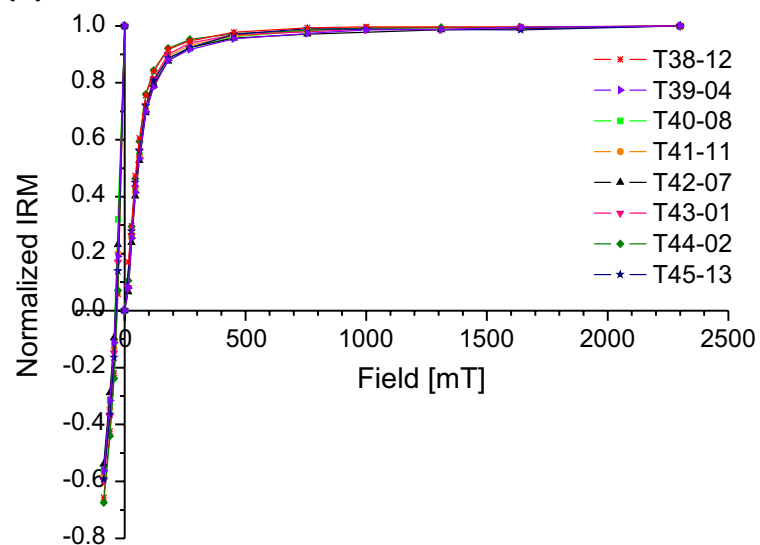

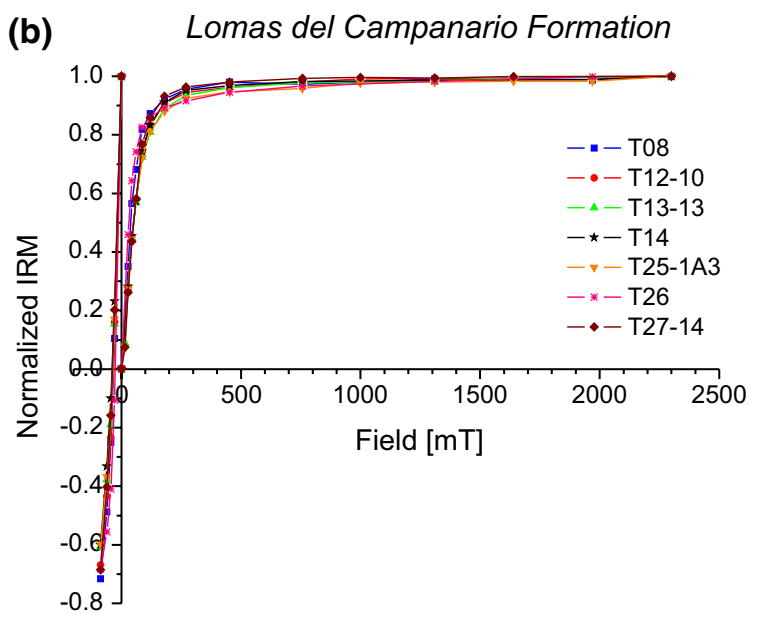

(d) Young Quaternary alluvial deposits

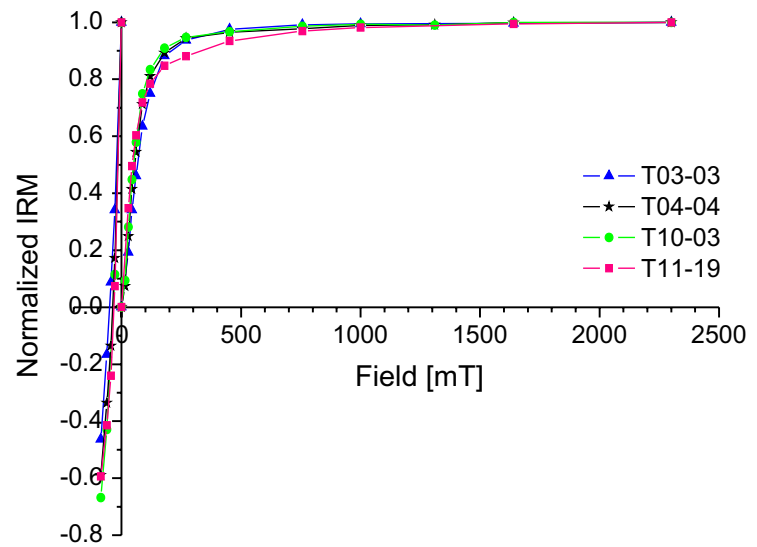

Fig. 6 Normalized isothermal remanent magnetization (IRM) acquisition curves in magnetic fields up to $2300 \mathrm{mT}$ and associated backfield curves of samples from: a Las Flores Formation, b Lomas del Campanario Formation, $\mathbf{c}$ AQAD and $\mathbf{d}$ YQAD 
Table 3 Remanent coercive force $B_{\text {cr }}$ as estimated from backfield curves of Fig. 6

\begin{tabular}{|c|c|c|}
\hline Geologic unit & Sample & $B_{\mathrm{cr}}(\mathrm{mT})$ \\
\hline \multirow[t]{6}{*}{ Las Flores Formation } & T30-03 & 36 \\
\hline & $\mathrm{T} 31-1 \mathrm{C} 1$ & 55 \\
\hline & T32-2A1 & 37 \\
\hline & T32-2B & 52 \\
\hline & T33-2B & 200 \\
\hline & T33-3B & 508 \\
\hline \multirow[t]{7}{*}{ Lomas del Campanario Formation } & T08 & 36 \\
\hline & $\mathrm{T} 12-10$ & 34 \\
\hline & T13-13 & 35 \\
\hline & $\mathrm{T} 14$ & 37 \\
\hline & T25-1A3 & 36 \\
\hline & $\mathrm{T} 26$ & 14 \\
\hline & $\mathrm{T} 27-14$ & 36 \\
\hline \multirow[t]{8}{*}{ Ancient Quaternary alluvial deposits } & T38-12 & 31 \\
\hline & T39-04 & 38 \\
\hline & T40-08 & 40 \\
\hline & $\mathrm{T} 41-11$ & 38 \\
\hline & T42-07 & 39 \\
\hline & T43-01 & 37 \\
\hline & $\mathrm{T} 44-02$ & 32 \\
\hline & $\mathrm{T} 45-13$ & 35 \\
\hline \multirow[t]{4}{*}{ Young Quaternary alluvial deposits } & T03-03 & 52 \\
\hline & T04-04 & 37 \\
\hline & $\mathrm{T} 10-03$ & 44 \\
\hline & T11-19 & 19 \\
\hline
\end{tabular}

To summarize, titanomagnetite with variable titanium content to pure magnetite is the dominant mineral that carries the characteristic magnetic remanence in Lomas del Campanario Formation, AQAD, YQAD and some samples from Las Flores Formation. Subordinate contribution of haematite is observed in these units. Goethite is the main antiferromagnetic mineral of high coercivity in sites T31, $\mathrm{T} 32$ and T33, while haematite is present in sites T30, T31 and T33 from the Las Flores Formation.

Frequency dependence parameter $k_{\mathrm{fd}}$ on a selected number of specimens of the four geologic units showed a mean value of $2.8 \%$ (Table 5). If the result of sample T33-2B (with $k_{f \mathrm{~d}}=7.9 \%$ ) is ignored, all parameters are below $4.2 \%$. Then, no significant frequency dependence of susceptibility was found for the complete collection of samples (i.e. superparamagnetic fraction contribution is negligible). Thermomagnetic curves compatible with SD and MD grains support this result (Dearing 1994).

SIRM acquisition and demagnetization crossover plots from seven samples of the four geologic units (representative cases are shown in Fig. 9) indicate $R$ points with $x$ values in the range 13-31 $\mathrm{mT}$ and $y$ values in the interval 0.15-0.26. Considering the crossover plot of magnetite by Symons and Cioppa (2000), the average effective (not actual) domain size of the magnetic carriers is PSD for six of these samples and MD for the sample T38-12 $(x=13, y=0.15)$.

\section{Vertical-axis rotations}

Vertical-axis rotations were estimated in the directionspace approach (Beck 1989). When sites from the same zone showed similar directions, a single mean direction was computed from all samples for the whole zone. This may imply the presence of quasi-rigid blocks; however, as shown below, this is likely an oversimplification of the rheological behaviour along the El Tigre Fault but facilitates a first approach to the directional data analysis. The rotation of declination is given by $R=\mathrm{Do}-\mathrm{Dr}$, whereas the anomaly of inclination is determined by $F=\mathrm{Ir}-$ Io ("flattening" sensu Beck (1989)), where the observed palaeomagnetic direction is (Do, Io) and the reference direction is (Dr, Ir), which corresponds to the geocentric axial dipole field direction at the study area $(\mathrm{Dr}=0$ and $\mathrm{Ir}$ ranges from
Table 4 Fitting parameters from analytical method developed by Kruiver et al. (2001) on samples from zone A

\begin{tabular}{|c|c|c|c|c|c|c|c|c|}
\hline \multicolumn{9}{|c|}{ Zone A (Las Flores Formation) } \\
\hline \multirow[t]{3}{*}{ Sample } & \multicolumn{8}{|c|}{ Parameters } \\
\hline & \multicolumn{4}{|c|}{ Component 1} & \multicolumn{4}{|c|}{ Component 2} \\
\hline & SIRM1 & $\%$ SIRM & $B_{1 / 2}(\mathrm{mT})$ & DP & SIRM2 & $\%$ SIRM & $B_{1 / 2}(\mathrm{mT})$ & DP \\
\hline T30-03 & 0.80 & 94 & 50.1 & 0.28 & 0.05 & 6 & 794.3 & 0.40 \\
\hline $\mathrm{T} 31-1 \mathrm{C} 1$ & 0.11 & 84 & 56.2 & 0.33 & 0.02 & 16 & 1258.9 & 0.36 \\
\hline T32-2A1 & 1.00 & 100 & 61.0 & 0.14 & - & - & - & - \\
\hline T32-2B & 0.48 & 83 & 70.8 & 0.17 & 0.01 & 17 & 1000 & 0.21 \\
\hline T33-2B & 0.13 & 34 & 79.4 & 0.38 & 0.250 & 66 & 631 & 0.30 \\
\hline T33-3B & 0.13 & 33 & 70.8 & 0.30 & 0.260 & 67 & 1000 & 0.23 \\
\hline
\end{tabular}

SIRM: saturation of isothermal remanent magnetization; $B_{1 / 2}$ : applied field at which half of the SIRM is reached; DP: dispersion parameter 


\section{(a)}

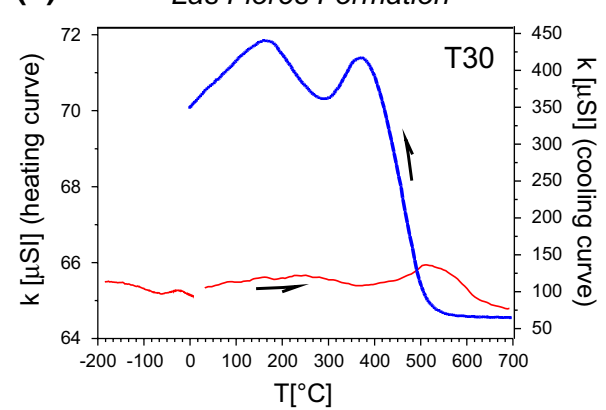

(d) Ancient Quaternary alluvial deposits

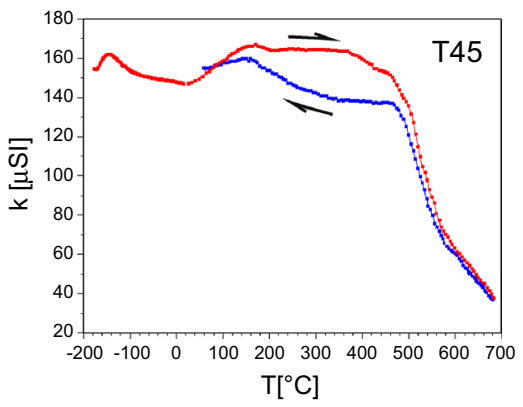

(b) Lomas del Campanario Formation

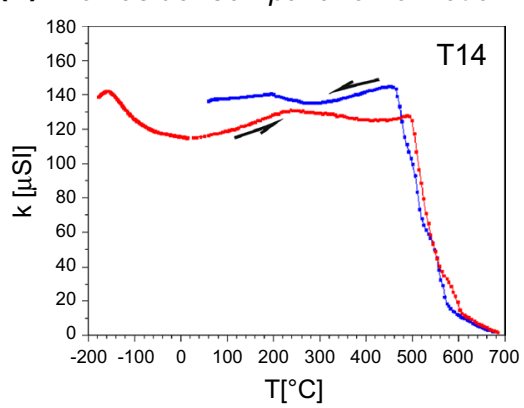

(e) Ancient Quaternary alluvial deposits

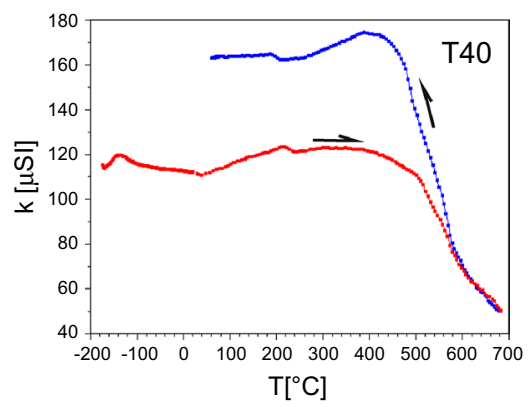

(c) Lomas del Campanario Formation

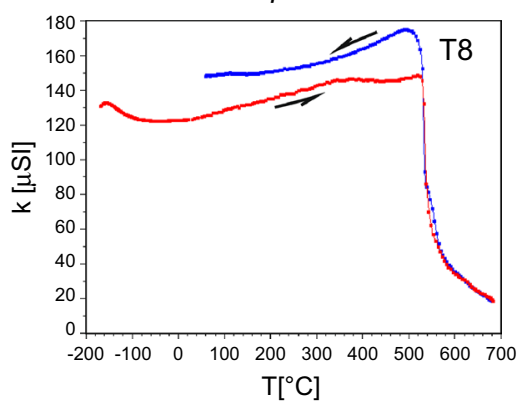

(f) Young Quaternary alluvial deposits

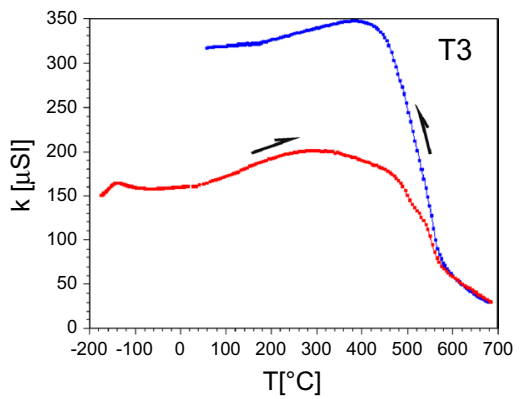

Fig. 7 Some representative low- and high-temperature thermomagnetic curves of samples from each geologic unit: a Las Flores Formation, b, c Lomas del Campanario Formation, d, e AQAD and f YQAD. Arrows indicate heating (red) or cooling (blue) sense
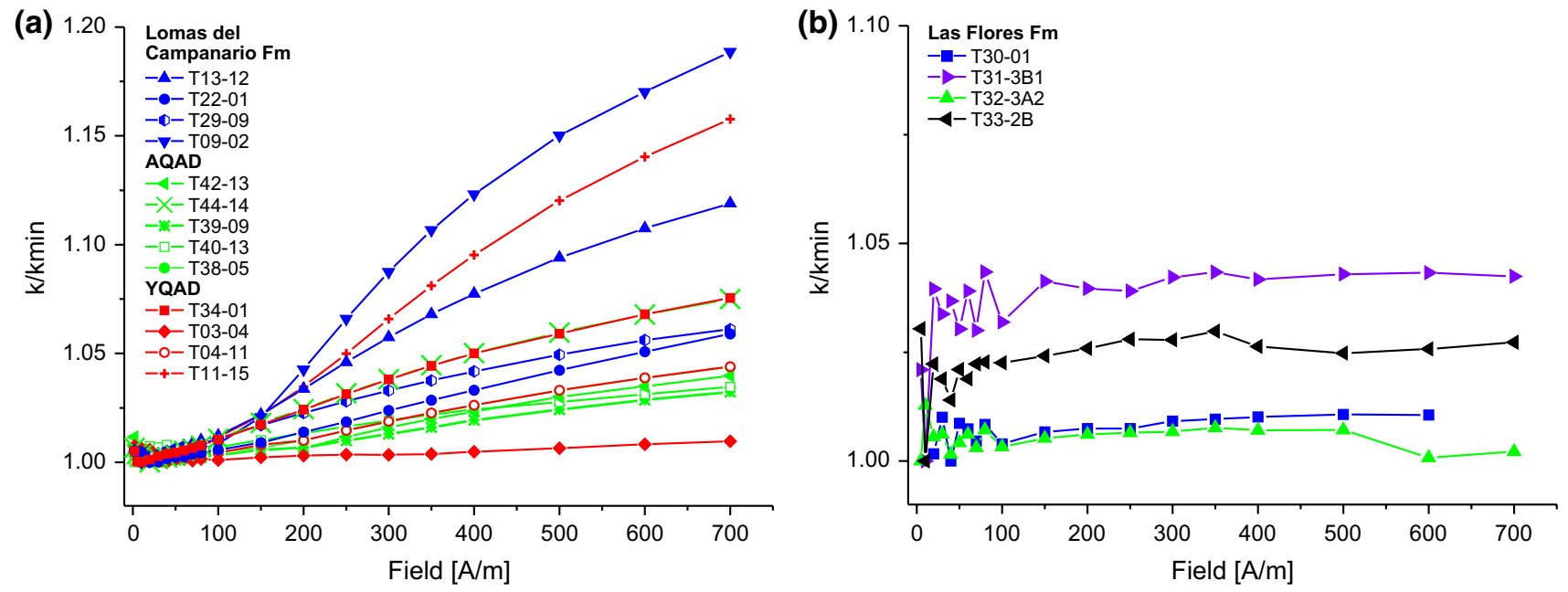

Fig. 8 Bulk magnetic susceptibility as a function of an external magnetic AC field with $H_{\text {peak }}$ from 2 to $700 \mathrm{Am}^{-1}$ at a fixed frequency of 976 Hz. a Lomas del Campanario Formation, AQAD and YQAD. b Las Flores Formation

$-49.6^{\circ}$ to $-50.1^{\circ}$ according to different latitudes of each zone). The same reference direction was assumed for the Late Miocene-Pliocene sediments, since drift of South America in the last 10 million years can be considered negligible (Besse and Courtillot 2002; Torsvik et al. 2008). The $95 \%$ confidence intervals associated with $R$ and $F$ are calculated as $\Delta R$ and $\Delta F$, respectively, according to Demarest
(1983). The results for each geological unit at each zone or isolated sites are given in Table 6. Computed rotations are indicated by arrows in Fig. 10 where cones represent $95 \%$ confidence limits, being the reference a north pointing arrow. The $95 \%$ confidence limit of the present-day axial dipole field direction is adopted as $3^{\circ}$, following Merrill and McElhinny (1983). 
Table 5 Frequency dependence of magnetic susceptibility parameter $k_{\mathrm{fd}}$ in selected samples of the four geologic units

\begin{tabular}{lrrrl}
\hline Geologic unit & Sample & \multicolumn{1}{l}{$k_{f 1}$} & \multicolumn{1}{c}{$k_{f 3}$} & $k_{f \mathrm{~d}}(\%)$ \\
\hline Las Flores Formation & T33-2B & 14.06 & 12.95 & 7.9 \\
& T32-3A & 10.10 & 9.82 & 2.8 \\
& T30-01 & 9.20 & 8.84 & 3.9 \\
Lomas del Campanario Formation & T36-16 & 4.68 & 4.55 & 2.8 \\
& T12-15 & 5.25 & 5.17 & 1.5 \\
& T13-12 & 5.98 & 5.82 & 2.7 \\
Ancient Quaternary alluvial deposits & T22-01 & 4.55 & 4.47 & 1.8 \\
& T45-04 & 3.27 & 3.20 & 2.1 \\
& T39-09 & 2.66 & 2.31 & 2.9 \\
& T40-13 & 1.19 & 1.14 & 4.2 \\
& T38-5B & 4.37 & 4.28 & 2.1 \\
Young Quaternary alluvial deposits & T10-01 & 10.74 & 10.57 & 1.6 \\
& T11-15 & 7.84 & 7.72 & 1.5 \\
& T03-04 & 1.90 & 1.85 & 2.6 \\
& T04-11 & 3.01 & 2.95 & 2.0 \\
\hline
\end{tabular}

Susceptibility values $k_{\mathrm{f} 1}$ and $k_{\mathrm{f} 3}$ are expressed in $10^{-3}$ (SI), except for Las Flores Formation, which is in $10^{-5}$ (SI)

Several observations are made considering the rotation values of the four geologic units (Table 6). (a) Las Flores Formation. The estimated vertical-axis rotation in zone $\mathrm{A}$ of $83.9^{\circ} \pm 17.9^{\circ}$ indicates a very large clockwise (CW) rotation of at least $66^{\circ}$ of these outcrops. (b) Lomas del Campanario Formation. (i) Zones B and D have virtually identical and smaller but significant $\mathrm{CW}$ rotations, $R=19.9^{\circ} \pm 9.0^{\circ}$ and $R=17.3^{\circ} \pm 12.7^{\circ}$, respectively. (ii) The mean direction of sites $\mathrm{T} 14$ and $\mathrm{T} 15$, which are located very near the fault trace in zone $\mathrm{E}$, reveals a $\mathrm{CW}$ rotation of much larger magnitude: $59.8^{\circ} \pm 17.9^{\circ}$. (iii) Large anticlockwise $(\mathrm{ACW})$ rotations were detected in zone $\mathrm{E}$ as well as in zone G. Mean results from sites T22 and T27 in zone $\mathrm{E}$ indicate an $\mathrm{ACW}$ rotation of $-65.0^{\circ} \pm 9.8^{\circ}$. These sites are situated $250 \mathrm{~m}$ to the west of the fault trace in the Quebrada Grande. Sites T6 (reverse polarity) and T8 in zone $\mathrm{G}$ yield similar declination anomalies; however, site T6 shows a very large flattening. In this case, therefore, only site T8 was considered for estimating the vertical-axis rotation at this zone, which yielded an ACW rotation of $-73.2^{\circ} \pm 10.4^{\circ}$. The contrasting results within zone $\mathrm{E}$ and of zones $\mathrm{E}$ and $\mathrm{G}$ with respect to other zones indicate an area with a complex kinematic pattern. (c) Ancient Quaternary alluvial deposits. (i) No significant rotation was identified for site $\mathrm{T} 43$ in the zone $\mathrm{E}\left(R=-5.8^{\circ} \pm 9.2^{\circ}\right)$. (ii) The isolated site T42 reveals a $\mathrm{CW}$ rotation of $19.1^{\circ} \pm 13.6$. (iii) $\mathrm{An} \mathrm{ACW}$ rotation has been identified in the zone F-G $\left(R=-18.5^{\circ} \pm 10.6^{\circ}\right.$ ). (iv) Zone $\mathrm{H}$ (sites $\mathrm{T} 38, \mathrm{~T} 39, \mathrm{~T} 40$ and T41) is much larger than the previous ones, suggesting that the resolution of the results is reduced. Declination of the characteristic components for sites T38, T39 and T40 is positive and small; meanwhile, site $\mathrm{T} 41$ shows an important ACW rotation of $-43.0^{\circ} \pm 14.5^{\circ}$. Considering that sites T39 and T41 belong to the same stratigraphic level, that they are $177 \mathrm{~m}$ apart and that no structural discontinuity is observed between them, we excluded site T41 in the computation of the mean rotation of this zone (see "Discussion" section). Thus, it is interpreted that zone $\mathrm{H}$ may have suffered a small but significant $\mathrm{CW}$ rotation of $9.6^{\circ} \pm 6.3^{\circ}$ since deposition of the AQAD. (d) Young Quaternary alluvial deposits. Values with $R=10.4^{\circ} \pm 12.3^{\circ}$ and $R=4.4^{\circ} \pm 6.3^{\circ}$ were observed at zones $\mathrm{C}$ and $\mathrm{F}$, respectively. This means that no significant rotations affected these deposits.

\section{Magnetic fabrics}

The anisotropy of magnetic susceptibility (AMS) of twenty-five sites (360 samples) was determined (Table 7; Fig. 11). The site-mean bulk magnetic susceptibility $(k)$ spans over three orders of magnitude, from $3.6 \times 10^{-5}$ to $1.6 \times 10^{-2}$ SI. Correlation between bulk susceptibility and lithology is observed. Mean bulk susceptibility of all specimens of the Las Flores Formation is $8 \times 10^{-5} \mathrm{SI}$; while those of the Lomas del Campanario Formation, AQAD and YQAD are in the order of $10^{-3} \mathrm{SI}$.

The $T-P_{j}$ plot (Jelínek 1978; Fig. 12) for the complete set of specimens shows that samples with low anisotropy degree fall both in the oblate and in the prolate fields, and those with higher anisotropy are mostly oblate-shaped. For the site-means, the degree of anisotropy $\left(P_{j}\right)$ is moderate to low for all sites (most values are below 1.10). Only one site, T25, shows an anisotropy degree of around $12 \%$. This type of distribution is characteristic of undeformed or weakly deformed sediments (see Mattei et al. 2004; Cifelli et al. 2005; Chadima et al. 2006).

Magnetic rock studies suggest that the anisotropy of magnetic susceptibility is controlled mostly by PSD and/ or MD magnetite. Well-defined Curie temperatures at ca. $580{ }^{\circ} \mathrm{C}$ as determined from the thermomagnetic curves (Fig. 7) indicate Ti-poor magnetite as the principal mineral governing the bulk susceptibility, at least in the Lomas del Campanario Formation, AQAD and YQAD. Considering this, the results of the crossover plots (Fig. 9) and the welldeveloped Verwey transition observed in most low-temperature curves indicate PSD to MD magnetite for all the geologic units (Figs. 7, 9). Moreover, a mineralogical control of the magnetic fabric seems unlikely as the IRM acquisition curves (Fig. 6) are virtually identical irrespective of the type of magnetic fabric shown by the sampling site. This repetitive behaviour suggests a prevailing common mineralogy. The presence of mineralogically controlled inverse 

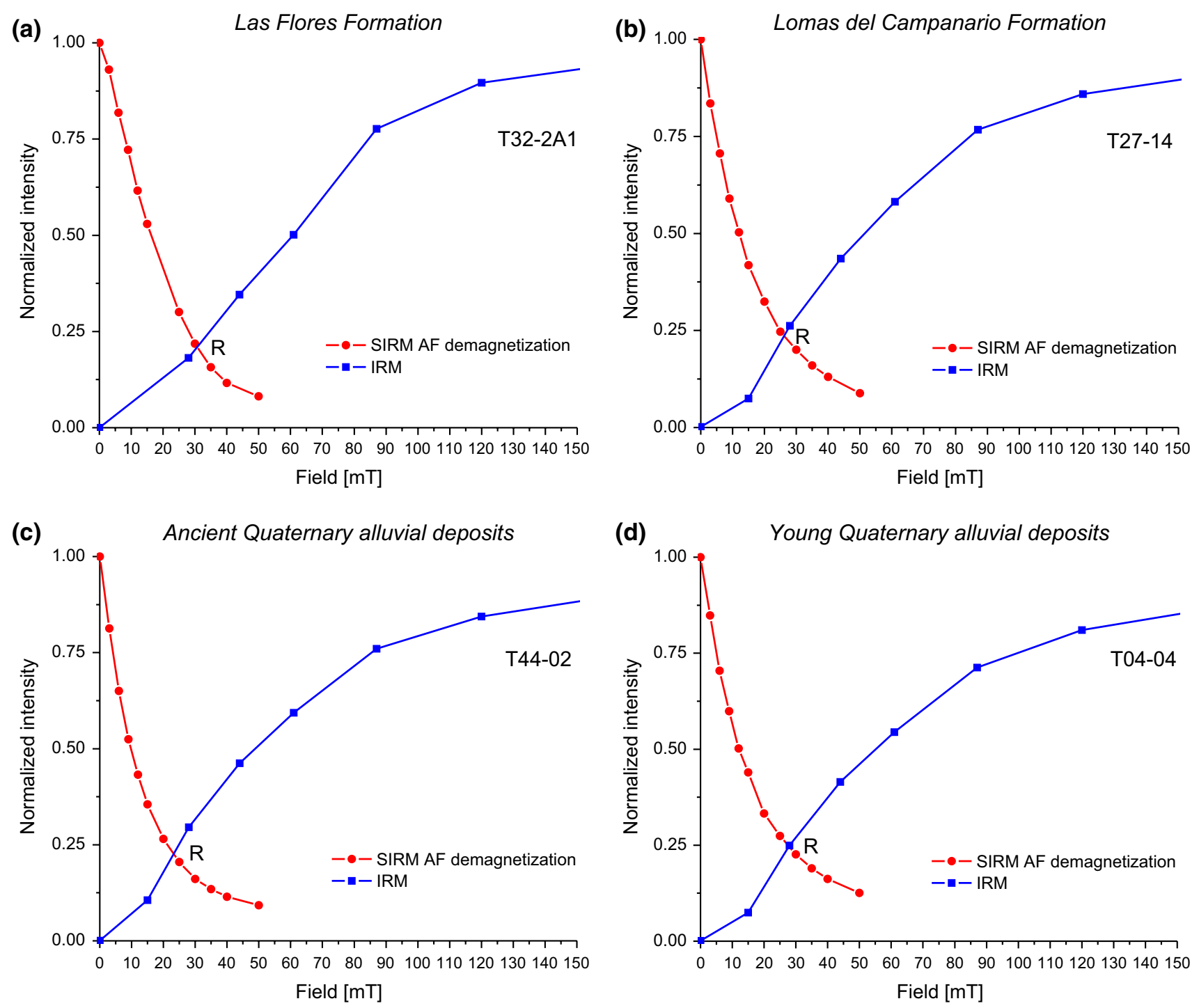

Fig. 9 Crossover plots of SIRM acquisition and AF demagnetization of SIRM of samples from: a Las Flores Formation, b Lomas del Campanario Formation, $\mathbf{c} A Q A D$ and $\mathbf{d}$ YQAD

or mixed magnetic fabrics (Rochette et al. 1992) is therefore highly unlikely. A normal magnetic fabric is then expected for the sampled sites, and a tectonic overprint of those "non-sedimentary" fabrics is interpreted.

With the exception of the folded Las Flores Formation, little or no macroscopic deformation was detected during field work. However, magnetic fabrics with different degrees of tectonic overprint were observed (Winkler et al. 1996). Examples of primary (sedimentary-compaction) fabrics are found in sites T10 (YQAD) and T25 (Lomas del Campanario Formation), a mild tectonic overprint is observed in T36 (Lomas del Campanario Formation) and T38 (AQAD), while a clear tectonic fabric is recognized in T9 (Lomas del Campanario Formation), T28 (Lomas del Campanario Formation) and T34 (YQAD), where sedimentary magnetic fabric seems completely obliterated. Principal magnetic susceptibility axes and strain directions are coaxial and define maximum stretching and maximum shortening directions in a magnetic fabric of tectonic origin. The axis associated with stretching or shortening depends on the degree of the tectonic overprint of the fabric. A pure depositional or compactional fabric is expected to be represented by the minimum susceptibility axis $\left(K_{3}\right)$ orthogonal to the bedding plane, while $K_{1}$ and $K_{2}$ are distributed along a girdle contained in the bedding plane. In early stages of deformation, the magnetic lineation $\left(K_{1}\right)$ clusters around the stretching direction, while the maximum shortening is indicated by the mean axis $K_{2}$ still on the bedding plane. As deformation progresses, $K_{2}$ and $K_{3}$ start forming a girdle in a plane orthogonal to 
Table 6 Palaeomagnetic rotations around vertical axes calculated on the basis of zonemean magnetic data and on some isolated sites (Table 2)

\begin{tabular}{lllrrrr}
\hline Unit & Zone & T sites & $R\left(^{\circ}\right)$ & $\Delta R\left(^{\circ}\right)$ & $F\left(^{\circ}\right)$ & $\Delta F\left(^{\circ}\right)$ \\
\hline Las Flores Formation & $\mathrm{A}$ & $30-32-33$ & 83.9 & 17.9 & 16.6 & 7.3 \\
Lomas del Campanario Formation & $\mathrm{B}$ & $1-2-25-26$ & 19.9 & 9.0 & 0.1 & 6.0 \\
& $\mathrm{D}$ & $12-13-36$ & 17.3 & 12.7 & -20.7 & 11.1 \\
& $\mathrm{E}$ & $14-15$ & 59.8 & 17.9 & -19.8 & 15.4 \\
& $\mathrm{E}$ & $22-27$ & -65.0 & 9.8 & -5.5 & 7.1 \\
& $\mathrm{G}$ & 6 & -65.9 & 5.6 & -49.9 & 5.6 \\
& $\mathrm{G}$ & 8 & -73.2 & 10.4 & -4.9 & 7.5 \\
Ancient Quaternary alluvial deposits & $\mathrm{E}$ & 43 & -5.8 & 9.2 & -14.7 & 7.6 \\
& $\mathrm{~F}-\mathrm{G}$ & $44-45$ & -18.5 & 10.6 & -0.8 & 7.1 \\
& - & 42 & 19.1 & 13.6 & -9.3 & 10.4 \\
& $\mathrm{H}$ & $41^{\mathrm{a}}$ & -43.0 & 14.5 & -13.5 & 11.7 \\
& $\mathrm{H}$ & $38-39-40$ & 9.6 & 6.3 & -13.2 & 5.2 \\
Young Quaternary alluvial deposits & $\mathrm{C}$ & $10-11$ & 10.4 & 12.3 & -15.6 & 10.2 \\
& $\mathrm{~F}$ & $3-4$ & 4.4 & 6.3 & -1.1 & 4.5 \\
\hline
\end{tabular}

$\mathrm{T}$ sites: sites involved in the statistical analysis; $\mathrm{R}$ : rotation of declination; $\mathrm{F}$ : flattening; $\Delta \mathrm{R}, \Delta \mathrm{F}: 95 \%$ confidence intervals associated with $\mathrm{R}$ and $\mathrm{F}$, respectively. The observed palaeomagnetic declination and inclination for the zone at a specific geologic unit (Do and Io, respectively) are given by the specimens mean (Table 2)

${ }^{\text {a }}$ Site $\mathrm{T} 41$ is excluded from the calculus of the mean rotation of zone $\mathrm{H}$ (a)

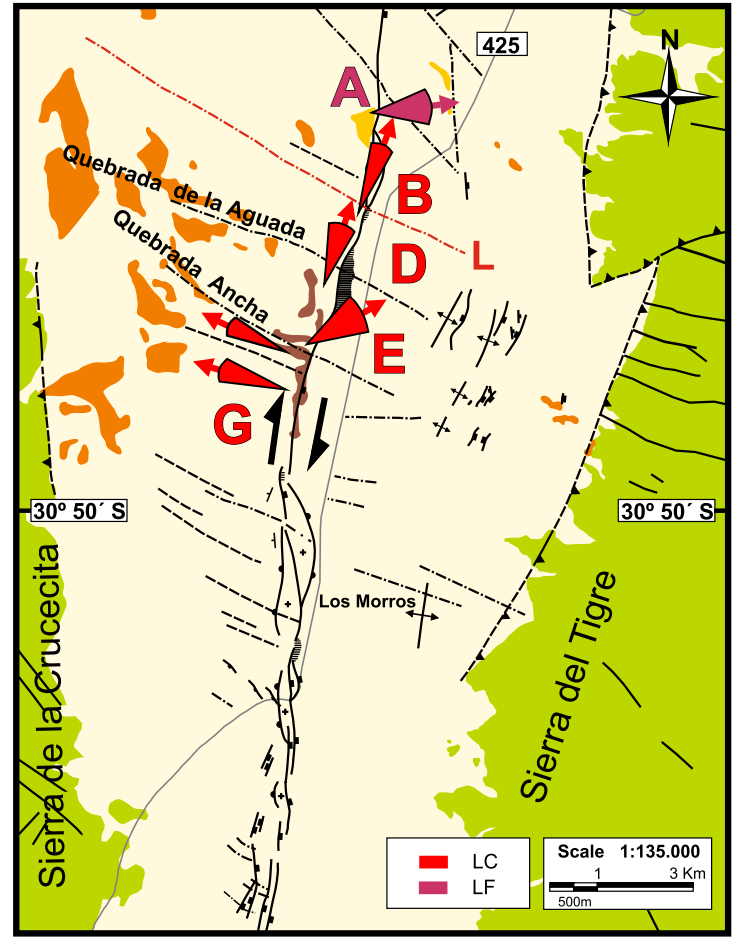

Fig. 10 Rotations around vertical axes in the central segment of the El Tigre Fault on top of the geologic map of Fig. 1a (see structural references there). a Las Flores Formation (zone $A$ ) and Lomas del

$K_{1}$. In the most advanced state, the maximum shortening is indicated by $K_{3}$ which becomes subhorizontal (Winkler et al. 1996). For example, fabrics from T3, T4 and T11 (YQAD, Fig. 11) show a low grade of deformation (b)

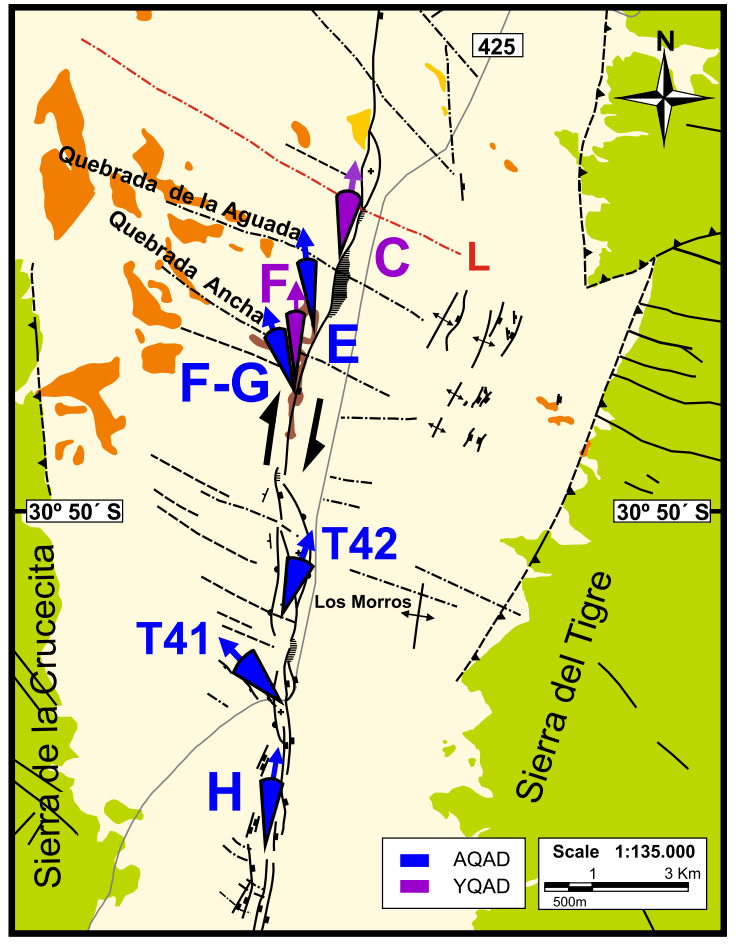

Campanario Formation (zones $B, D, E$ and $G$ ). b AQAD (site T42 and zones $E, F-G$ and $H$ ) and YQAD (zones $C$ and $F$ ). Cones represent $95 \%$ confidence regions

with the shortening direction given by the $K_{2}$ axis and the stretching direction given by the $K_{1}$ axis. This means that the magnetic fabric of all these sites shows an E-W shortening direction. 


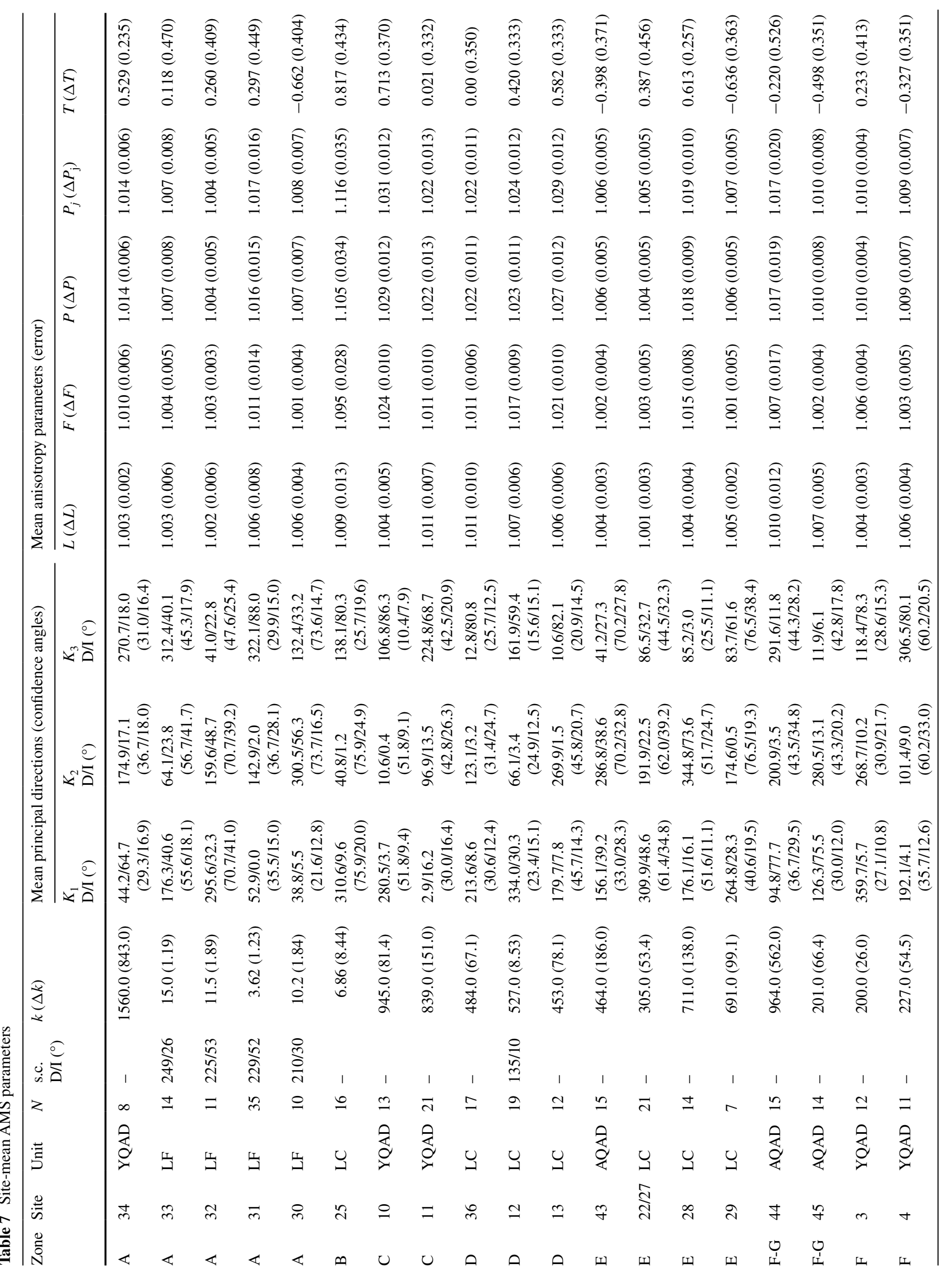




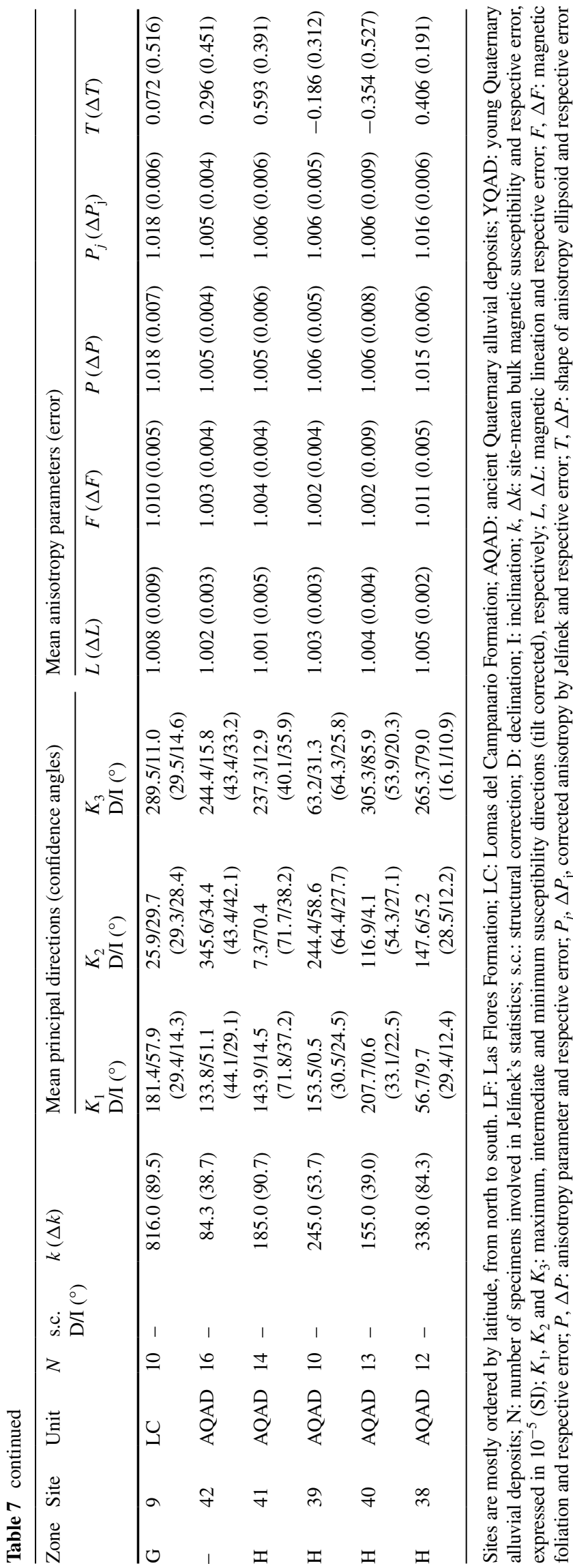

In order to evaluate the regional stretching direction, data of the site-mean $K_{1}$ axes of the four geologic units examined were plotted in a contour colour fill (equalarea projection) and a rose diagram (Fig. 13) by means of the Open Stereo software (Grohmann and Campanha 2009-2011). Data from Las Flores Formation and site T12 (Lomas del Campanario Formation, zone D) have been corrected for bedding attitude. Directions of principal axes of AMS were corrected by the amounts of vertical-axis rotation defined by the palaeomagnetic study, assuming that the magnetic fabric was fixed soon after deposition. Some particular sites were excluded from the analysis: T10 and T25, which show pure depositional fabrics (principal axes $K_{1}$ and $K_{2}$ are not well defined) and T9, T28 and T29 (no rotation data are available due to incoherent palaeomagnetic directions within each site). Though palaeomagnetic directions for site T34 (zone A, YQAD) are inconsistent, a null rotation is supposed, considering that no significant magnitude of rotation was found for sediments of the same age (zones $\mathrm{C}$ and F, YQAD). In this way, a total number of 20 principal susceptibility axes are subject to the analysis. The contour plot (Fig. 13a) shows that the point of maximum density $(10.3 \%)$ has a trend of $0^{\circ}\left(K_{1}\right.$ axes are considered in the northern hemisphere). Meanwhile, the rose diagram (Fig. 13b) shows a mean value of $(356.9 \pm 18.2)^{\circ}$. For this plot, data with inclinations greater than $45^{\circ}$ are omitted (in such case, the $K_{1}$ direction is not considered a good stretching indicator). The diagrams indicate that a $\mathrm{N}-\mathrm{S}$ trend of $K_{1}$ axes is suggested for the study areas.

\section{Discussion}

According to the results of the palaeomagnetic study, the kinematic behaviour of the central segment of the El Tigre Fault is interpreted as variable and complex. Large CW vertical-axis rotations $\left(>66^{\circ}\right)$ are implied by palaeomagnetic data at zone A (Las Flores Formation). On the other hand, smaller values of $\mathrm{CW}$ rotation $\left(\sim 20^{\circ}\right)$ have been detected in the outcrops of the Lomas del Campanario Formation at zones B and D. Hence, the presence of a firstorder morphostructural discontinuity (Principal Lineament L, Fig. 1a), which was first determined by geomorphic and structural studies (Fazzito 2011; Fazzito et al. 2013) and later by electrical resistivity tomography (Bello Camilletti 2012), is now confirmed by the very different palaeomagnetic pattern observed on Miocene rocks to the north (zone A) and south (zone B) of this lineament. Although the whole El Tigre Fault is characterized by dominant dextral strike-slip, the described geologic features (see "The El Tigre Fault" section) imply a different kinematic regime to the north of L (zone A, particularly) with more "pure" strike-slip behaviour, in contrast to a larger component of 


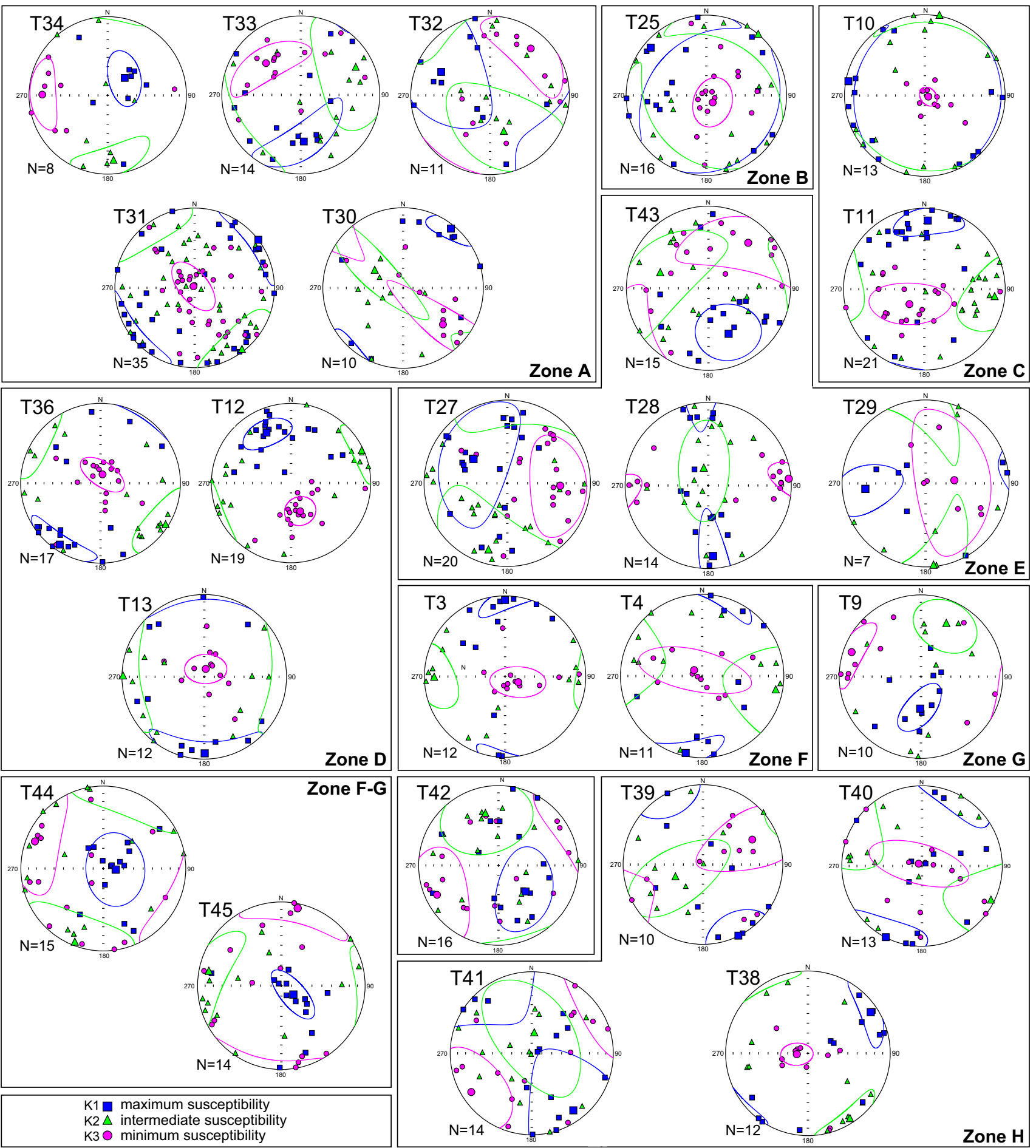

Fig. 11 Anisotropy of low-field magnetic susceptibility plots in equal-area projections, lower hemisphere (bedding corrected data). Square, triangle and circle symbols correspond to maximum, inter-

normal displacement to the south of $\mathrm{L}$. This means that $\mathrm{L}$ has worked, at least at some time in the fault history, as a mechanical discontinuity that separates two areas of different kinematic behaviours. Large rotations have also mediate and minimum principal directions of susceptibility anisotropy, respectively. Ovals: $95 \%$ confidence regions of the mean axis. Sites are mostly arranged by latitude

been identified in the Lomas del Campanario Formation (Miocene-lower Pliocene) at zone E (Table 6; Fig. 10a). A $\mathrm{CW}\left(\sim 60^{\circ}\right)$ is suggested by data for sites next to the fault trace (sites T14 and T15, zone E), while, an ACW $\left(\sim-65^{\circ}\right)$ 


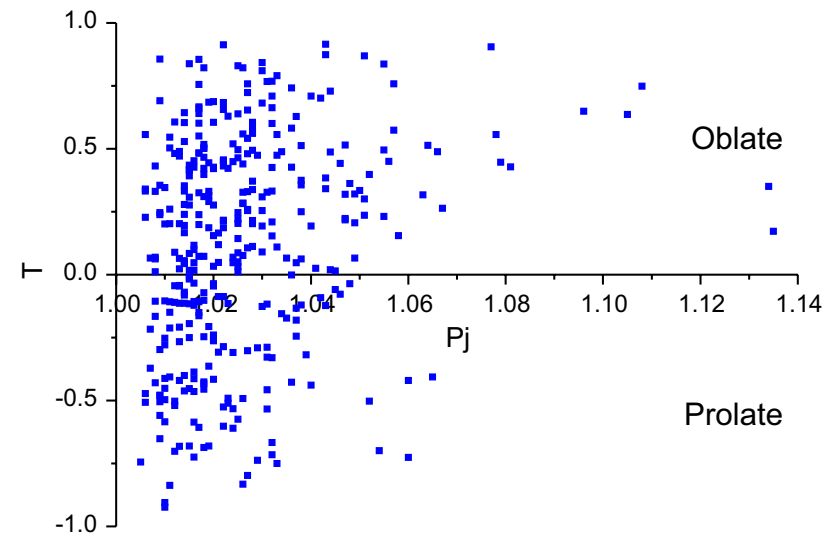

Fig. 12 Shape of anisotropy ellipsoid $\mathrm{T}$ as a function of anisotropy degree $P_{j}$

rotation was detected for the more distant sites (sites T22 and T27, zone E). Similar ACW rotation values $\left(\sim-70^{\circ}\right)$ were calculated for the same unit at zone G. However, the AQAD (middle Pleistocene) show very small to unsignificant values of vertical-axis rotations, i.e. an ACW rotation at zone $\mathrm{F}-\mathrm{G}\left(\sim-20^{\circ}\right)$, a $\mathrm{CW}$ rotation at site $\mathrm{T} 42\left(\sim 20^{\circ}\right)$, a $\mathrm{CW}$ at zone $\mathrm{H}$ of $\sim 10^{\circ}$ and a not significant value at site T43. The only exception is the large ACW rotation found at the isolated site T41 $\left(\sim-43^{\circ}\right)$. Finally, no significant rotations are indicated by data from YQAD (late Pleistocene, zones $\mathrm{C}$ and $\mathrm{F}$ ). Evidently, magnitudes of rotations are related to the age of the sampled geologic units. The largest values are detected at sites in Miocene-lower Pliocene strata, while minor tectonic deformation is identified for the youngest sediments (late Pleistocene age). This indicates that most of the rotations occurred in pre-middle Pleistocene times and suggest that deformation along the El Tigre Fault probably extends back at least into the Pliocene.
Large ACW rotations are somewhat unexpected, as dextral strike-slip systems, depending on the structural setting, tend to produce clockwise block rotations in simple structural models (e.g. Ron et al. 1984; Nur et al. 1986). In our case, sites with large ACW rotations correspond to areas where important oblique structures to the El Tigre Fault have been identified. In a specific case, both senses of rotation occur at sites located relatively close together (less than $4 \mathrm{~km}$ apart) in the same sampling zone E (sites T14 and $\mathrm{T} 15$ show a CW rotation, whereas T22 and T27 yield an ACW rotation, Fig. 10a). We propose that this peculiar distribution of significant rotations within a region of complex structures could be explained as the result of the tectonic interaction of the main fault with a system of secondary oblique faults. The horizontal displacement of the El Tigre Fault (central segment) could have (re)activated these oblique faults, which probably originated in pre-existing structures of the Palaeozoic basement. The reactivation of Palaeozoic or Mesozoic structures by Andean deformation has been detected very frequently in the Precordillera of San Juan and neighbouring areas (e.g. Ramos and Kay 1991; Cortés et al. 1997; Cortés 1998; Terrizzano et al. 2010, 2012). Small semi-rigid blocks constrained by the main fault and boundary faults (oblique structures) could have suffered simultaneous $\mathrm{CW}$ and ACW vertical-axis rotation as in a block rotation pattern with internal antithetic shear. For this type of setting (domino-like system), the faults that limit the blocks undergo an opposite displacement (left-lateral strike-slip) with respect to the principal system (right-lateral strike-slip). Typical kinematic deformation schemes in a dextral strike-slip fault system are discussed by Sylvester (1988), Itoh et al. (2003) and Kimura et al. (2004, 2011). The large magnitude of rotations (zones A, E and G) along the main fault as well as in secondary faults can be explained by drag deformation.
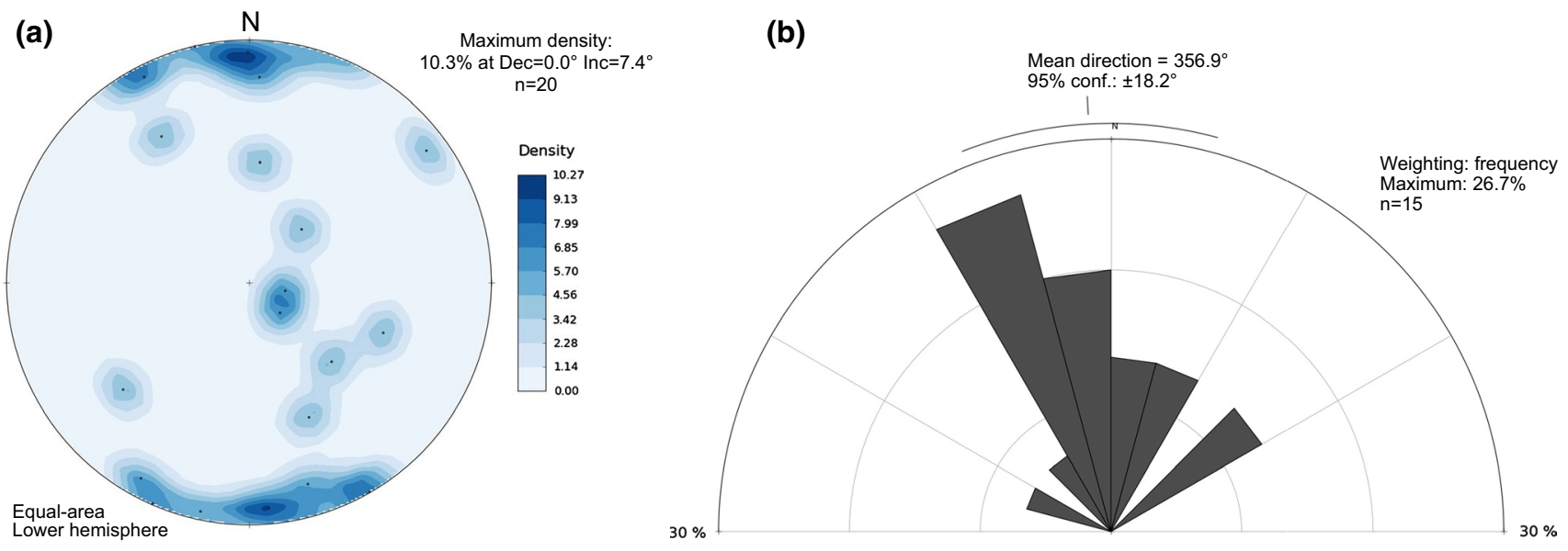

Fig. 13 Distribution of site-mean $K_{1}$ axes of the four studied geologic units (corrected by rotation). a Contour colour fill diagram. b Rose diagram (axes with inclinations over $45^{\circ}$ are omitted) 
(a)

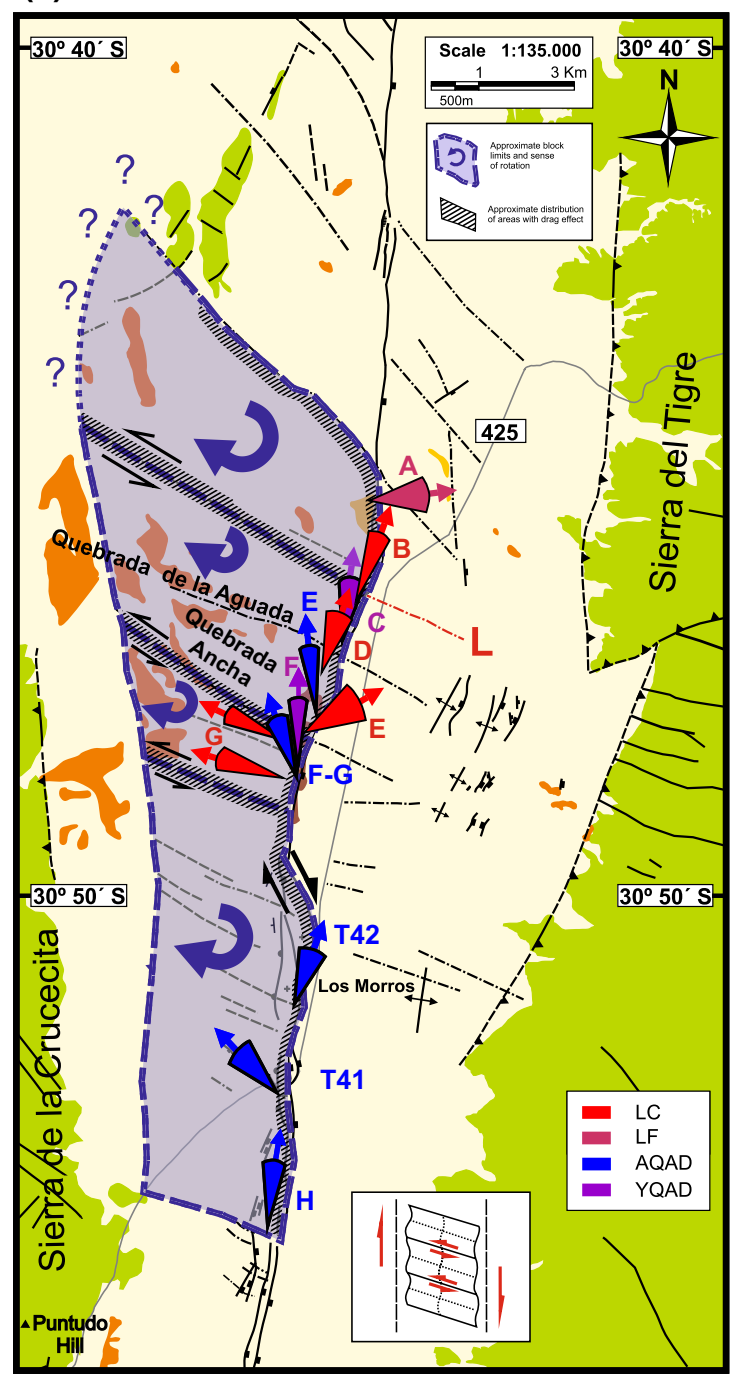

(b)

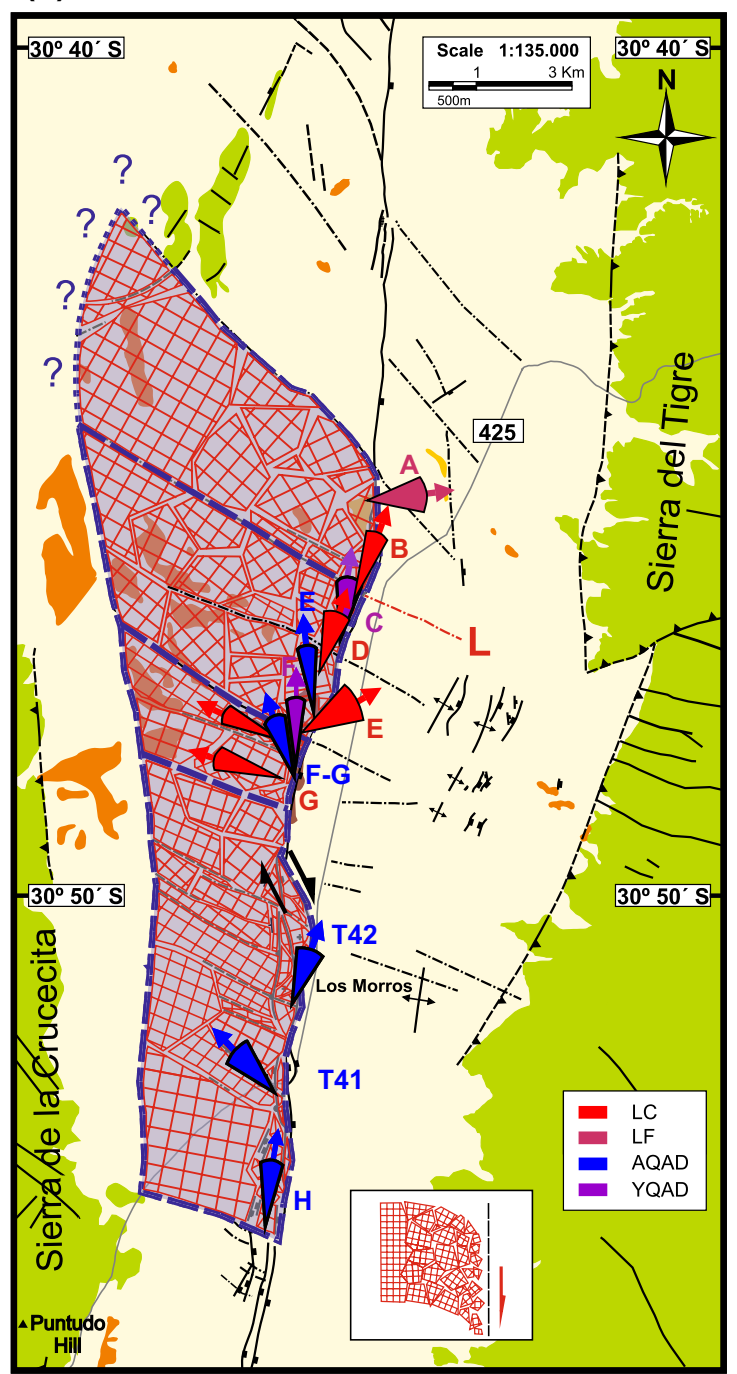

Fig. 14 a Bookshelf-like model with drag (Itoh et al. 2003) along the main and the secondary faults for the central segment of the El Tigre Fault. b Multiple small block model with variable internal rotation (Sylvester 1988)

This rules out a simple system of rotating rigid blocks as a viable kinematic model for the El Tigre Fault deformation. The lateral dimensions of the semi-rigid blocks and the limits of the broad deformation cannot be determined with the available data. Systematic palaeomagnetic sampling progressively farther from the main fault up to distances of several $100 \mathrm{~m}$ is required. The important fault zone in the western piedmont of Sierra del Tigre (Fig. 1a), possibly associated with a thrust zone (Fazzito 2011; Fazzito et al. 2013), probably indicates the maximum eastern extension of these blocks. To the west of the El Tigre Fault, the deformation has reached at least $420 \mathrm{~m}$ at the latitude of T2 (zone B), the most distant site that has been sampled from the main structure. A bookshelf-like pattern with significant drag (Fig. 14a) may probably be a first-order approximation to account for much of the observed palaeomagnetic data. However, a more complex pattern that includes many additional small blocks with variable rotations (Sylvester 1988) cannot be discarded (Fig. 14b), at least for some localities, considering the important $\mathrm{ACW}$ rotation found in several sites of the Lomas del Campanario Formation at zones $\mathrm{E}$ and $\mathrm{G}$ as well as in middle Pleistocene deposits of site T41 (Fig. 10b). The presence of different scarps in the vicinity of site T41 (Fig. 1a) shows neotectonic activity that could be responsible for this local behaviour. The simplified kinematic model for the central segment of the El Tigre Fault presented in Fig. 14a shows the Principal Lineament $\mathrm{L}$ and the lineament at Quebrada Ancha as block boundary faults. The smaller rotation of the Miocene-lower Pliocene sediments at zones $\mathrm{B}$ and $\mathrm{D}$ with respect to that of zones A, E and G may be due to (i) a minor drag effect along the main fault in these zones, (ii) an effect of location of sites 
considering the sinusoidal variation of the angle of rotation representative of a bookshelf model with drag (Itoh et al. 2003) or (iii) the existence of an almost rigid block that includes zones B, C and D. On the other hand, a more complex model like that presented in Fig. 14b is possible. However, the density of sampling is far from being adequate to reconstruct with some precision the extension, shape and magnitude of rotation of each block. The available data only permit a very preliminary approximation to such possibility. The fact that no rotations have been registered for the YQAD is probably due to the short time elapsed since deposition. Although the vertical displacements in the AQAD are large (tens of metres), the displacements in the YQAD are less significant, and they are represented by small piedmont scarps $(<2 \mathrm{~m})$ and uplifted fluvial terraces, indicative of the fact that they have undergone much lesser tectonic disturbance.

The significance of the small rotation values determined for the AQAD (with the only exception of site T41) can be questioned as to whether they reflect actual rotations or incomplete average of palaeosecular variation. This is likely not the case for the Las Flores and Lomas del Campanario formations in which both polarities of the Earth Magnetic Field were recorded and show much larger declination deviations. For the AQAD, we calculated the total angular standard dispersion $S_{T}$ (McElhinny and Merrill 1975; McElhinny and McFadden 1997) of the VGPs computed on a specimen basis (see data in Online Resource 1). In order to reduce the influence of experimental errors in the dispersion value, the within-site dispersion $S_{w}$ (average dispersion) was computed (McElhinny and Merrill 1975), so that the VGP dispersion $S_{F}$ is given by $S_{F}^{2}=S_{T}^{2}-\left(S_{W}^{2} \tilde{n}\right)$, where $\tilde{n}$ is the average number of samples per site. The value of $S_{F}$ is $16.8^{\circ}$ for zone $\mathrm{H}$ (34 specimens), $21.2^{\circ}$ for zone F-G (17 specimens) and $23.2^{\circ}$ for the entire set (70 specimens). Other zones or sites were not included due to a smaller number of observations. The VGP angular dispersion averaged for the last $5 \mathrm{Ma}$ at $\sim 30^{\circ}$ of latitude is below $13^{\circ}$ (McFadden et al. 1988). Other works (Lund 1985, 2007) have reported even lower values for the VGP angular dispersion averaged over intervals of $10^{3}$ and $10^{5}$ year. The value computed for the entire set of VGPs is significantly higher than expected suggesting the presence of CW and ACW tectonic rotations affecting it. This is supported by the fact that those corresponding to zones $\mathrm{H}$ and $\mathrm{F}-\mathrm{G}$, although still higher than expected, are smaller than that for the overall mean. For this reason, we conclude that the computed values of rotations for the AQAD are unlikely due to non-averaged palaeosecular variation and likely reflect true tectonic rotations.

Further research on the deformation pattern of the fault, which includes a quantitative estimation of the cumulative strike-slip crustal deformation, should give a more precise evaluation of the seismic hazard of the region.

\section{Conclusions}

Palaeomagnetism can provide a quantitative characterization of deformation associated with strike-slip faults. Here, the combination of this approach with magnetic fabric studies on non-consolidated to poorly consolidated MioPliocene and younger sediments of diverse age reveals evidence of significant and variable vertical-axis rotations along the central segment of the El Tigre Fault. Rotation values versus age of the affected sediments indicate that most of the rotations, and therefore probably the activity of the fault, took place before the middle Pleistocene, perhaps since the Pliocene. The presence of oblique structures together with the identification of clockwise and anticlockwise rotations allows us to suggest simplified kinematic models of the El Tigre Fault based either in a domino-like scheme with drag along the main and secondary faults or a more complex pattern of rotation with numerous heterogeneous blocks that rotate in different senses and magnitudes. The absence of significant rotations on late Pleistocene deposits could be the effect of lack of enough time for measurable deformation. Magnetic fabric studies show tectonic overprint in most of the sediments, even when no visible macroscopic deformation was observed in the field. Application of palaeomagnetic rotations to the AMS axes suggests a $\mathrm{N}-\mathrm{S}$ trend in the maximum regional stretching direction.

Acknowledgments The authors are very grateful for the financial support from Universidad de Buenos Aires (UBACyT 20020100100778 and UBACyT X262 Grants) and CONICET (PIPCONICET 11220080102295 Grant). ASTER satellite imagery was kindly provided by SEGEMAR. We would like to thank Daniel Pérez for collaborating on the generation of the mosaic. Comments by John W. Geissman on an earlier version of this paper are acknowledged. We appreciate the help from Mabel Mena on the calculation of the angular dispersion of VGPs. We wish to thank Belén Oliva-Urcia and Manuel Calvo-Rathert for their careful and thorough reviews.

\section{References}

Allmendinger RW, Figueroa D, Snyder D, Beer J, Mpodozis C, Isacks BL (1990) Foreland shortening and crustal balancing in the Andes at $30^{\circ} \mathrm{S}$ Latitude. Tectonics 9:789-809

Alonso (2010) Estratigrafía, sistemas depositacionales y aspectos composicionales del relleno neógeno de la cuenca Rodeo-Iglesia, San Juan, Argentina. Tesis doctoral. Facultad de Ciencias Exactas y Naturales, Universidad de Buenos Aires, Buenos Aires

Aparicio EP (1984) Geología de San Juan. Facultad de Ciencias Exactas, Físicas y Naturales, Universidad Nacional de San Juan, San Juan 
Basile YA (2004) Estudio geológico y geofísico del sector sur de las Lomas del Inca, provincia de San Juan. Trabajo final de Licenciatura. Facultad de Ciencias Exactas y Naturales, Universidad de Buenos Aires

Bastías HE, Bastías JA (1987) Fallamiento rumbo-deslizante en el borde oriental de los Andes entre los 32 y 26 grados de latitud sur. $10^{\circ}$ Congreso Geológico Argentino. Actas 1:207-210

Bastías HE, Weidmann NE, Pérez AM (1984) Dos zonas de fallamiento Pliocuaternario en la Precordillera de San Juan. $9^{\circ}$ Congreso Geológico Argentino. Actas 2:329-341

Bastías HE, Uliarte E, de Paredes JD, Sanchez A, Bastías JA, Ruzycki L, Perucca P (1990) Neotectónica de la provincia de San Juan. $11^{\circ}$ Congreso Geológico Argentino. Relatorio de geología y recursos naturales de la Provincia de San Juan, pp 228-244

Bastías HE, Tello GE, Perucca LP, de Paredes JD (1993) Peligro sísmico y neotectónica. $12^{\circ}$ Congreso Geológico Argentino y $2^{\circ}$ Congreso de Exploración de Hidrocarburos (Mendoza). In: Ramos VA (ed) Geología y Recursos Naturales de Mendoza, vol 6 , issue no 1, pp 645-658

Beck ME Jr (1989) Paleomagnetism of continental North America; implications for displacement of crustal blocks within the Western Cordillera, Baja California to British Columbia. Geol Soc Am Mem 172:471-492

Bello Camilletti G (2012) Estudio geológico y geofísico del segmento central de la falla El Tigre, San Juan, Argentina. Tesis de Licenciatura, Universidad de Buenos Aires

Besse J, Courtillot V (2002) Apparent and true polar wander and the geometry of the geomagnetic field over the last $200 \mathrm{Myr}$. J Geophys Res 107(B11):2300

Cardó R, Díaz IN (2005) Memoria Hoja Geológica 3169-I, Rodeo. Servicio Geológico Minero Argentino, Buenos Aires

Chadima M, Jelínek V (2009) Anisoft 4.2. Anisotropy data browser. AGICO Inc, Czech Republic

Chadima M, Hrouda F, Melichar R (2006) Magnetic fabric study of the SE Rhenohercynian Zone (Bohemian Massif): implications for dynamics of the Paleozoic accretionary wedge. Tectonophysics 418:93-109

Cifelli F, Mattei M, Chadima M, Hirt A, Hansen A (2005) The origin of tectonic lineation in extensional basins: combined neutron texture and magnetic analyses on "undeformed" clays. Earth Planet Sci Lett 235:62-78

Contreras VH, Damiani O, Milana JP, Bracco AI, Barrera OM (1990) Paleógeno y Neógeno de San Juan. 11 ${ }^{\circ}$ Congreso Geológico Argentino. Actas, pp 154-185

Cortés JM (1998) Tectónica de desplazamiento de rumbo en el borde sur de la depresión de Yalguaraz, Mendoza, Argentina. Rev Assoc Geol Argent 53(2):147-157

Cortés JM, Cegarra M (2004) Plegamiento cuaternario transpresivo en el piedemonte suroccidental de la Precordillera sanjuanina. Rev Asoc Geol Argent Serie D Publicación Especial 7:68-75

Cortés JM, González Bonorino G, Koukharsky ML, Pereyra FX, Brodtkorb A (1997) Hoja 3369-03, Yalguaraz, Provincias de San Juan y Mendoza. Servicio Geológico Minero Argentino

Cortés JM, Vinciguerra P, Yamín M, Pasini MM (1999) Tectónica

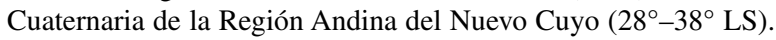
In: Caminos R (ed) Geología Argentina, Subsecretaría de Minería de la Nación, Servicio Geológico Minero Argentino. Anales, Buenos Aires, vol 29, issue no 24, pp 760-778

Cortés JM, Pasini MM, Yamin G (2005a) Paleotectonic controls on the distribution of Quaternary deformation in Southtern Precordillera, Central Andes $\left(31^{\circ} 30^{\prime}-33^{\circ} \mathrm{SL}\right)$. International Symposium on Andean Geodynamics, extended abstracts, pp 186-189, Barcelona

Cortés JM, Yamín MG, Pasini MM (2005b) La Precordillera Sur, Provincias de Mendoza y San Juan, $16^{\circ}$ Congreso Geológico Argentino, La Plata. Actas 1:395-402
Cortés JM, Casa A, Pasini MM, Yamin MG (2005c) Fajas de estructuras neotectónicas asociadas a rasgos paleotectónicos en Precordillera y Cordillera Frontal $\left(31^{\circ} 30^{\prime}-33^{\circ} 30^{\prime} \mathrm{LS}\right) .16^{\circ}$ Congreso Geológico Argentino, La Plata. Actas 4:463-466

Cortés JM, Casa A, Pasini MM, Yamin MG, Terrizzano CM (2006) Fajas oblicuas de deformación neotectónica en Precordillera y Cordillera Frontal $\left(31^{\circ} 30^{\prime}-33^{\circ} 30^{\prime} \mathrm{LS}\right)$. Controles paleotectónicos Rev Asoc Geol Argent 61(4):639-646

Costa C, Machette MN, Dart RL, Bastías E, Paredes ND, Perucca LP, Tello GE, Haller KM (2000) Map and database of quaternary faults and folds in Argentina, United States Geological Survey Open-File Reports, 00-108

Costa CH, Audemard MFA, Bezerra FHR, Lavenu A, Machette MN, París G (2006) An overview of the main quaternary deformation of South America. Rev Assoc Geol Argent 61(4):461-479

Dearing JA (1994) Environmental magnetic susceptibility: using the Bartington MS2 system. Chi Publishing, Kenilworth

Demarest HH Jr (1983) Error analysis for the determination of tectonic rotation from paleomagnetic data. J Geophys Res 88(B5):4321-4328

Dunlop DJ, Özdemir Ö (1997) Rock magnetism. Fundamentals and frontiers. Cambridge University Press, Cambridge

England P, Wells RE (1991) Neogene rotations and quasicontinuous deformation of the Pacific Northwest continental margin. Geology 19:978-981

Fazzito SY (2011) Estudios geofísicos aplicados a la neotectónica de la falla El Tigre, Precordillera de San Juan. Tesis doctoral. Facultad de Ciencias Exactas y Naturales, Universidad de Buenos Aires, Buenos Aires

Fazzito SY, Cortés JM, Rapalini AE, Terrizzano CM (2013) The geometry of the active strike-slip El Tigre Fault, Precordillera of San Juan, Central-Western Argentina: integrating resistivity surveys with structural and geomorphological data. Int J Earth Sci 102:1447-1466

Fisher RA (1953) Dispersion on a sphere. Proc R Soc Lond A 217:295-306

Gagliardo M, Caselli A, Limarino O, Colombo Piñol F, Tripaldi A (2001) Las unidades terciarias de la Cuenca Rodeo-Iglesia: validez y correlación de las unidades formacionales. Rev Assoc Geol Argent 56(1):121-125

Grohmann CH, Campanha GAC (2009-2011) OpenStereo. Opensource multiplatform stereonet analysis for structural geology. Institute of Geosciences, University of São Paulo

Hernandez-Moreno C, Speranza F, Di Chiara A (2014) Understanding kinematics of intra-arc transcurrent deformation: paleomagnetic evidence from the Liquiñe-Ofqui fault zone (Chile, $38-41^{\circ} \mathrm{S}$ ): Rotation along the Liquiñe-Ofqui fault. Tectonics 33:1964-1988

Hrouda F, Chlupáčová M, Mrázová Š (2006) Low-field variation of magnetic susceptibility as a tool for magnetic mineralogy of rocks. Phys Earth Planet Inter 154:323-336

INPRES (1977) Zonificación sísmica de la República Argentina. Instituto Nacional de Prevención Sísmica. Publicación Técnica no 5, San Juan

INPRES (1982) Microzonificación sísmica del valle de Tulúm, provincia de San Juan. Instituto Nacional de Prevención Sísmica. Resumen Ejecutivo, San Juan

Isacks B, Barazangi M (1977) Geometry of Benioff zones: lateral segmentation and downwards bending of the subducted lithosphere. In: Talwani M, Pitman W (eds) Island Arcs, Deep Sea Trenches and Back Arc Basins, American Geophysical Union, Ewing Series 1, pp 99-114

Itoh Y, Kimura H, Doshida S (2003) Active strike-slip faulting and macroscopically nonrigid deformation of volcanic rocks in central Japan inferred from a paleomagnetic study. Tectonophysics 374:81-89

Itoh Y, Kusumoto S, Furubayashi T (2008) Quantitative evaluation of Quaternary crustal deformation around the Takayama 
Basin, central Japan: a paleomagnetic and numerical modeling approach. Earth Planet Sc Lett 267:517-532

Jelínek V (1978) Statistical processing of anisotropy of magnetic susceptibility measured on groups of specimens. Stud Geophys Geod 22:50-62

Johnson AT, Jordan TE, Johnson NM, Naeser C (1987) Cronología y velocidad de sedimentación en una secuencia volcaniclástica, Rodeo, Prov. de San Juan, Rep. Argentina. $10^{\circ}$ Congreso Geológico Argentino, Tucumán. Actas 2:87-90

Jordan TE, Isacks BL, Allmendinger RW, Brewer JA, Ramos VA, Ando CJ (1983a) Andean tectonics related to geometry of subducted Nazca plate. Geol Soc Am Bull 94(3):341-361

Jordan TE, Isacks B, Ramos VA, Allmendinger RW (1983b) Mountain building in the Central Andes. Episodes 3:20-26

Jordan T, Kelley S, Fernández A, Fernández Seveso F, Re G, Milana JP (1997) Relaciones entre las historias evolutivas de las cuencas de Iglesia y Bermejo, provincia de San Juan, Argentina. $2^{\circ}$ Jornadas sobre Geología de Precordillera, San Juan. Actas 1:142-147

Kay SM, Abbruzzi JM (1996) Magmatic evidence for Neogene lithospheric evolution of the Central Andean flat-slab between 30 and $32^{\circ} \mathrm{S}$. Tectonophysics 259:15-28

Kimura H, Itoh Y, Tsutsumi H (2004) Quaternary strike-slip crustal deformation around an active fault based on paleomagnetic analysis: a case study of the Enako fault in central Japan. Earth Planet Sci Lett 226:321-334

Kimura H, Ishikawa N, Sato H (2011) Estimation of total lateral displacement including strike-slip offset and broader drag deformation on an active fault: tectonic geomorphic and paleomagnetic evidence on the Tanna fault zone in central Japan. Tectonophysics 501:87-97

Kirschvink JL (1980) The least-squares line and plane and the analysis of paleomagnetic data. Geophys J Int 62:669-718

Kruiver PP, Dekkers MJ, Heslop D (2001) Quantification of magnetic coercivity components by the analysis of acquisition curves of isothermal remanent magnetization. Earth Planet Sci Lett 189:269-276

Larrasoaña JC, Gómez-Paccard M, Giralt S, Roberts AP (2011) Rapid locking of tectonic magnetic fabrics in weakly deformed mudrocks. Tectonophysics 507:16-25

Lund SP (1985) A comparison of the statistical secular variation recorded in some late quaternary lava flows and sediments, and its implications. Geophys Res Lett 12:251-254

Lund SP (2007) Paleomagnetic secular variation. In: Gubbins D, Herrero-Bervera E (eds) Encyclopedia of geomagnetism and paleomagnetism. Springer, The Netherlands, pp 766-776

Mattei M, Speranza F, Argentieri A, Rossetti F, Sagnotti L, Funiciello R (1999) Extensional Tectonics in the Amantea basin (Calabria, Italy): a comparison between structural and magnetic anisotropy data. Tectonophysics 307:33-49

Mattei M, D’Agostino N, Zananiri I, Kondopoulou D, Pavlides S, Spatharas V (2004) Tectonic evolution of fault-bounded continental blocks: comparison of paleomagnetic and GPS data in the Corinth and Megara basins (Greece). J Geophys Res 109:B02106

Mattei F, Cifelli G, Muttoni A, Zanchi F, Berra F, Mossavvari SA (2012) Neogene block-rotation in Central Iran: evidence from paleomagnetic data. Geol Soc Am Bull 124(5-6):943-956

McElhinny MW, McFadden PL (1997) Paleosecular variation over the past $5 \mathrm{Myr}$ based on a new generalized database. Geophys J Int 131:240-252

McElhinny MW, Merrill RT (1975) Geomagnetic secular variation over the past 5 m.y. Rev Geophys 13(5):687-708

McFadden PL, Merrill RT, McElhinny MW (1988) Dipole/quadrupole family modeling of paleosecular variation. J Geophys Res 93:11583-11588

Merrill RT, McElhinny MW (1983) The Earth's magnetic field: its history, origin, and planetary perspective. Academic Press, New York
Nagy EA, Sieh KE (1993) The use of paleomagnetic analysis to assess nonbrittle deformation within the San Andreas Fault Zone. J Geophys Res 98:17965-17979

Nelson M, Jones C (1987) Paleomagnetism and crustal rotations along a shear zone, Las Vegas Range, southern Nevada. Tectonics 6(1):13-33

Nur A, Ron H, Scotti O (1986) Fault mechanics and the kinematics of block rotations. Geology 14:746-749

Parés JM (2015) Sixty years of anisotropy of magnetic susceptibility in deformed sedimentary rocks. Front Earth Sci 3(4):1-13

Peters C, Dekkers MJ (2003) Selected room temperature magnetic parameters as a function of mineralogy, concentration and grain size. Phys Chem Earth 2:659-667

Ramos VA, Kay SM (1991) Triassic rifting and associated basalts in the Cuyo Basin, central Argentina. In: Harmon RS, Rapela CW (eds) Andean magmatism and its tectonic setting, Geol Soc Am, Special paper 265, pp 79-91

Ramos VA, Cristallini EO, Pérez DJ (2002) The Pampean flat-slab of the Central Andes. J S Am Earth Sci 15(1):59-78

Re G (1994) Magnetoestratigrafía de la secuencia neogénica aflorante en arroyo Chaleta (Angualasto, San Juan), sus implicancias tectosedimentarias. $5^{\circ}$ Jornadas Argentinas de Sedimentología, Tucumán. Abstracts, pp 205-209

Re G, Barredo S (1993) Estudio magnetoestratigráfico y tasa de sedimentación del Grupo Iglesia en sus afloramientos aledaños a la localidad de Angualasto (Prov. de San Juan). $12^{\circ}$ Congreso Geológico Argentino. Actas 2:148-155

Robertson DJ, France DE (1994) Discrimination of remanence-carrying minerals in mixtures, using isothermal remanent magnetisation acquisition curves. Phys Earth Planet Int 82:223-234

Rochette P, Jackson M, Aubourg C (1992) Rock magnetism and the interpretation of anisotropy of magnetic susceptibility. Rev Geophys 30(3):209-226

Ron H, Freund R, Garfunkel Z, Nur A (1984) Block rotation by strike-slip faulting: structural and paleomagnetic evidence. J Geophys Res 89(B7):6256-6270

Sagnotti L, Winkler A, Montone P, Di Bella L, Florindo F, Mariucci MT, Marra F, Alfonsi L, Frepoli A (1999) Magnetic anisotropy of Plio-Pleistocene sediments from the Adriatic margin of the northern Apennines (Italy): implications for the time-space evolution of the stress field. Tectonophysics 311:139-153

Salyards SL, Sieh KE, Kirschvink JL (1992) Paleomagnetic measurement of nonbrittle coseismic deformation across the San Andreas fault at Pallett Creek. J Geophys Res 97(B9):12457-12470

Siame LL (1998) Cosmonucléide produit in situ $\left({ }^{10} \mathrm{Be}\right)$ et quantification de la déformation active dans les Andes centrales. Thèse de doctorat. Université de Paris-Sud, Orsay

Siame LL, Sébrier M, Bellier O, Bourles DL, Castano JC, Araujo M, Yiou F, Raisbeck GM (1996) Segmentation and horizontal sliprate estimation of the El Tigre Fault Zone, San Juan Province (Argentina) from SPOT images analysis. Third ISAG, St Malo, France. Abstracts: 239-241

Siame LL, Bourles DL, Sébrier M, Bellier O, Castano JC, Araujo M, Perez M, Raisbeck GM, Yiou F (1997a) Cosmogenic dating ranging from 20 to $700 \mathrm{ka}$ of a series of alluvial fan surfaces affected by the El Tigre Fault, Argentina. Geology 25(11):975-978

Siame LL, Sébrier M, Bellier O, Bourlès DL, Castano JC, Araujo M (1997b) Geometry, segmentation and displacement rates of the El Tigre Fault, San Juan Province (Argentina) from SPOT image analysis and ${ }^{10} \mathrm{Be}$ datings. Ann Tecton 1(2):3-26

Siame LL, Bellier O, Sebrier M (2006) Active tectonics in the Argentine Precordillera and western Sierras Pampeanas. Rev Assoc Geol Argent 61(4):604-619

Sonder LJ, Jones CH, Salyards SL, Murphy KM (1994) Vertical axis rotations in the Las Vegas Valley Shear Zone, southern Nevada: 
paleomagnetic constraints on kinematics and dynamics of block rotations. Tectonics 13(4):769-788

Sylvester AG (1988) Strike-slip faults. Geol Soc Am Bull 100:1666-1703

Symons DTA, Cioppa MT (2000) Crossover plots: a useful method for plotting SIRM data in paleomagnetism. Geophys Res Lett 27:1779-1782

Tauxe L (1998) Paleomagnetic principles and practice. Kluwer, Dordrecht, p 299

Terrizzano CM (2010) Neotectónica del extremo noroccidental del cinturón Barreal-Las Peñas, Precordillera Sur. Tesis doctoral. Facultad de Ciencias Exactas y Naturales, Universidad de Buenos Aires

Terrizzano CM, Fazzito SY, Cortés JM, Rapalini AE (2010) Studies of quaternary deformation zones through geomorphic and geophysical evidence: a case in the Precordillera Sur, Central Andes of Argentina. Tectonophysics 490(3-4):184-196

Terrizzano CM, Fazzito SY, Cortés JM, Rapalini AE (2012) Electrical resistivity tomography applied to the study of neotectonic structures, northwestern Precordillera Sur, Central Andes of Argentina. J S Am Earth Sci 34:47-60

Torsvik TH, Brinden JC, Smethurst MA (2000) Super-IAPD2000. Interactive analysis of palaeomagnetic data. Geological Survey of Norway, Trondheim, Norway

Torsvik TH, Müller RD, Van der Voo R, Steinberger B, Gaina C (2008) Global plate motion frames: toward a unified model. Rev Geophys 46:3004

Vallejo MD (2004) Estudio geológico y geofísico del sector norte de Lomas del Inca, Barreal del Leoncito, San Juan. Trabajo final de
Licenciatura. Facultad de Ciencias Exactas y Naturales, Universidad de Buenos Aires

Watson GS, Enkin RJ (1993) The fold test in paleomagnetism as a parameter estimation problem. Geophys Res Lett 20:2135-2137

Weidmann R, Cardinal A, Simon W (1985) Propuesta de ordenamiento de la nomenclatura estratigráfica de las sedimentitas terciarias de la Precordillera sanjuanina. Primeras Jornadas sobre geología de Precordillera, San Juan. Actas 1:342-347

Wetten C (1975a) Geología del valle de Iglesia, su relación con los yacimientos de diatomita de Lomas del Campanario e importancia económica. Trabajo final de Licenciatura. Facultad de Ciencias Exactas, Físicas y Naturales, Universidad Nacional de San Juan

Wetten C (1975b) Estudio geológico económico de un yacimiento de diatomita y análisis de mercado. $2^{\circ}$ Congreso Iberoamericano de Geología Económica. Actas 5:513-529

Winkler A, Florindo F, Sagnotti L, Sarti G (1996) Inverse to normal magnetic fabric transition in an Upper Miocene Marly Sequence from Tuscany, Italy. Geophys Res Lett 23:909-912

Worm H-U, Clark D, Dekkers MJ (1993) Magnetic susceptibility of pyrrhotite: grain size, field and frequency dependence. Geophys J Int 114:127-137

Yamin MG (2007) Neotectónica del bloque Barreal, margen noroccidental de la Precordillera Sur. Tesis doctoral. Facultad de Ciencias Exactas y Naturales, Universidad de Buenos Aires

Zijderveld JDA (1967) The natural remanent magnetization of the Exeter Volcanic Traps (Permian, Europe). Tectonophysics $4: 121-153$ 